\title{
Hydrogeologic Setting and Hydrologic Data of the Smoke Creek Desert Basin, Washoe County, Nevada, and Lassen County, California, Water Years 1988-90
}

By Douglas K. Maurer

UNITED STATES GEOLOGICAL SURVEY

Water-Resources Investigations Report 93-4043

Prepared in cooperation with the

REGIONAL WATER PLANNING AND ADVISORY BOARD-

RENO-SPARKS AND WASHOE COUNTY and the

CALIFORNIA DEPARTMENT OF WATER RESOURCES

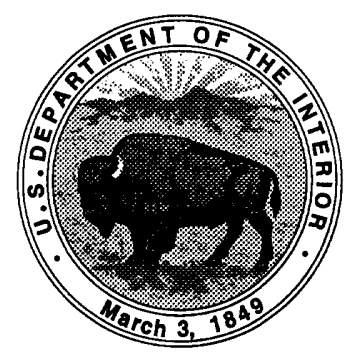




\title{
U.S. DEPARTMENT OF THE INTERIOR BRUCE BABBITT, Secretary
}

\author{
U.S. GEOLOGICAL SURVEY \\ ROBERT M. HIRSCH, Acting Director
}

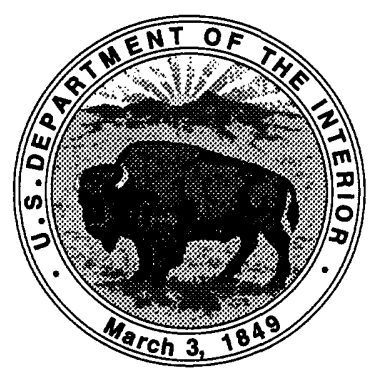

Any use of trade names in this pubiication is for descriptive purposes only and does not imply endorsement by the U.S. Government.

For additional information write to:

District Chief

U.S. Geological Survey 333 West Nye Lane, Room 203

Carson City, NV 89706-0866
Copies of this report can be purchased from:

U.S. Geological Survey Earth Science Information Center Open-File Reports Section Box 25286, MS 517 Denver Federal Center Denver, CO 80225-0046 


\section{CONTENTS}

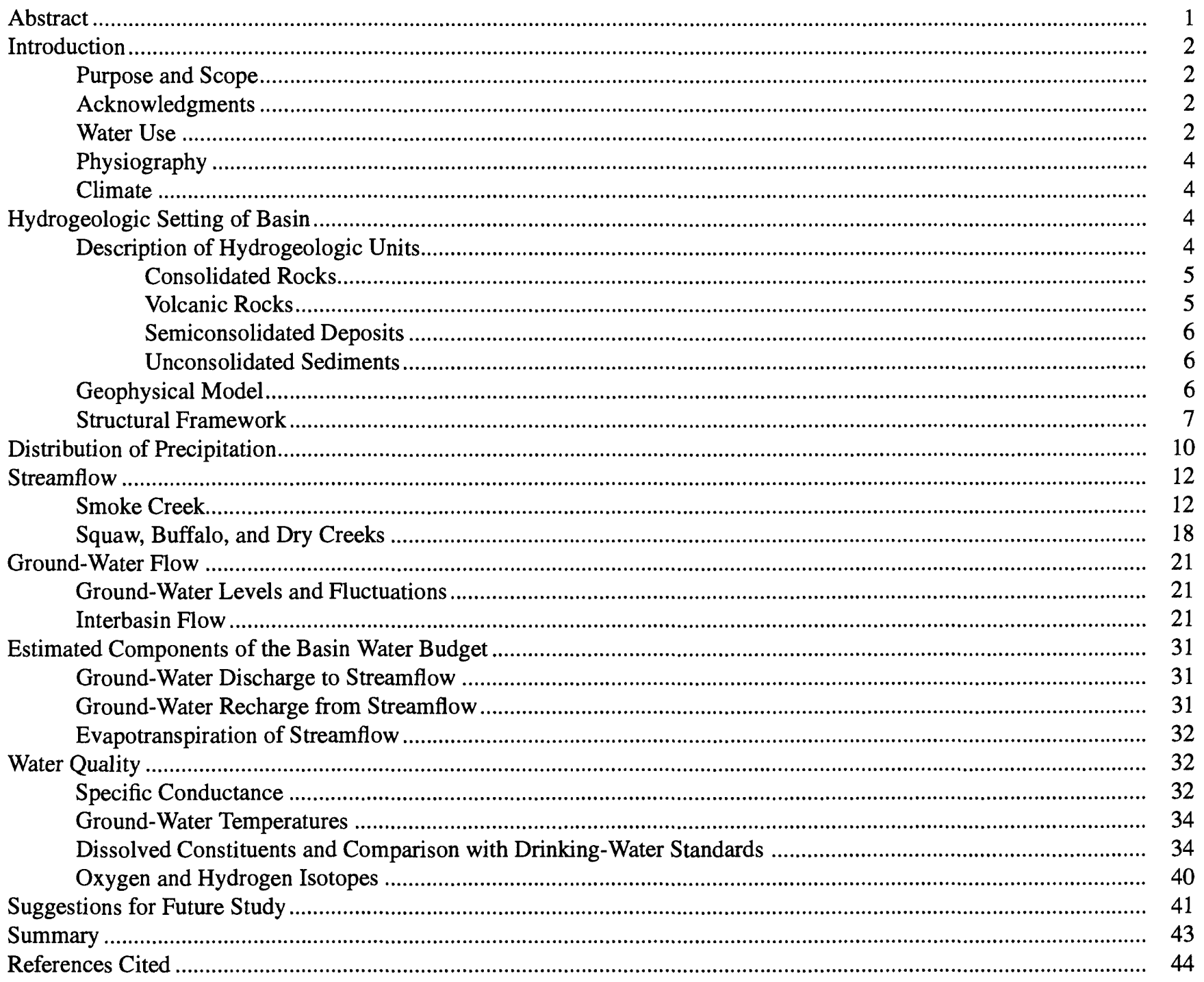




\section{PLATES}

[Plates are in pocket]

1-2. Maps of Smoke Creek Desert basin showing:

1. Generalized geology and location of geophysical profiles

2. Specific conductance and temperature of water from wells, springs, and surface-water sites, water years 1988-90

\section{FIGURES}

1. Map showing the location of Smoke Creek Desert basin and the study area boundary

2. Cross sections showing geologic model of Smoke Creek Desert basin and measured and calculated magnetic profiles

3-6. Maps showing:

3. Relation of Smoke Creek Desert basin to physiographic and geologic features .......................................

4. Distribution of average annual precipitation in Smoke Creek Desert basin ............................................. 11

5. Daily mean precipitation recorded at Espil Ranch and daily mean streamflow of Smoke Creek, water years 1989 and 1990

6. Location of miscellaneous streamflow measurements and amount of channel loss or gain along five reaches of Smoke Creek in July and November 1989.

7. Graph of daily minimum temperature at Espil Ranch during October and November 1989.

8. Map of surface-water and ground-water data-collection networks developed for the study area

9. Map of average water-level altitudes for selected wells in Smoke Creek Desert basin and adjacent basins during 1988 and 1989, as well as estimated direction and volume of ground-water flow.....

10. Graphs of fluctuations of water levels in selected wells, water years 1988-90............................................ 30

11. Graph of relation of specific conductance to well depth in Smoke Creek Desert basin .................................. 33

12. Stiff diagrams showing concentrations of major ions at selected sites

13. Map showing sampling sites, deuterium and oxygen-18 ratios, and radon-222 activities of ground water in Smoke Creek Desert basin.

14. Graph showing deuterium and oxygen-18 composition of ground water in Smoke Creek Desert basin and ground water in Honey Lake basin

\section{TABLES}

1. Precipitation data for Smoke Creek Desert stations

2. Miscellaneous streamflow data from Smoke Creek Desert basin, water years, 1988-90

3. Data from crest-stage gages in Smoke Creek Desert basin, water years 1989-90.

4. Water level, pressure head, flow rate, specific conductance, and water temperature of well, spring, and surface water in Smoke Creek Desert basin.

5. Quality of ground water in Smoke Creek Desert basin and drinking-water standards for public water systems in Nevada...

6. Deuterium and oxygen-18 composition and radon-222 activities of ground water sampled in Smoke Creek Desert and Honey Lake basins 


\begin{tabular}{|c|c|c|}
\hline Multiply & By & To obtain \\
\hline acre & 0.4047 & square hectometer \\
\hline acre-foot (acre-ft) & 1,233 & cubic meter \\
\hline acre-foot per year (acre-ft/yr) & 0.001233 & cubic hectometer per year \\
\hline cubic foot per second $\left(\mathrm{ft}^{3} / \mathrm{s}\right)$ & 0.02832 & cubic meter per second \\
\hline foot $(\mathrm{ft})$ & 0.3048 & meter \\
\hline inch (in.) & 25.40 & millimeter \\
\hline inch per year (in/yr) & 25.40 & millimeter per year \\
\hline mile (mi) & 1.609 & kilometer \\
\hline square mile $\left(\mathrm{mi}^{2}\right)$ & 2.590 & square kilometer \\
\hline
\end{tabular}

Temperature: Degrees Celsius $\left({ }^{\circ} \mathrm{C}\right)$ can be converted to degrees Fahrenheit $\left({ }^{\circ} \mathrm{F}\right)$ by using the formula ${ }^{\circ} \mathrm{F}=\left[1.8\left({ }^{\circ} \mathrm{C}\right)\right]+32$. Degrees Fahrenheit can be converted to degrees Celsius by using the formula ${ }^{\circ} \mathrm{C}=0.556\left({ }^{\circ} \mathrm{F}-32\right)$.

Sea level: In this report, "sea level" refers to the National Geodetic Vertical Datum of 1929 (NGVD of 1929, formerly called "Sea-Level Datum of 1929"), which is derived from a general adjustment of the first-order leveling networks of the United States and Canada.

Abbreviated water-quality umits: $\mathrm{g} / \mathrm{cm}^{3}$ (gram per cubic centimeter)

L (liter) $\mathrm{mg} / \mathrm{L}$ (milligram per liter) $\mathrm{mL}$ (milliliter)

$\mathrm{pCi} / \mathrm{L}$ (picocurie per liter)

$\mu \mathrm{g} / \mathrm{L}$ (microgram per liter)

$\mu \mathrm{m}$ (micrometer)

$\delta$ permil (delta units in parts per thousand)

$\mu \mathrm{S} / \mathrm{cm}$ (microsiemens per centimeter at $25^{\circ} \mathrm{C}$ ) 


\title{
Hydrogeologic Setting and Hydrologic Data of the Smoke Creek Desert Basin, Washoe County, Nevada, and Lassen County, California, Water Years 1988-90
}

\author{
By Douglas K. Maurer
}

\section{Abstract}

Smoke Creek Desert-a 1,200-squaremile basin north of Reno, Nevada-is a potential water source for urban development in Washoe County. Hydrogeologic data were collected to begin a detailed data base to refine the hydrologic budget for the basin. Impermeable granitic rocks form a boundary to ground-water flow on the east side of the basin and at the base of the flow system. Overlying the granitic basement, permeable volcanic rocks form a high, dissected plateau on the west and north sides of the basin and represent a previously unrecognized aquifer. Near the center of the basin, geophysical data indicate that basin-fill sediments are about 2,000 feet thick. The complex structural setting of the basin and the geometry of the aquifers are masked by overlying volcanic rocks and sediments and remain largely unknown. Ground water may flow through the permeable volcanic rocks over much of the western, northern, and southern boundaries of the basin; however, additional water-level data are needed to determine if interbasin flow takes place along these boundaries.

Periodic measurements of water levels, pressure head, flow rate, temperature, and specific conductance of ground water show little change from 1988 to 1990 except at one location near pumping for irrigation. The chemical composition of the ground water begins as a dilute sodium and calcium bicarbonate water in the mountain blocks, changes to a slightly saline sodium bicarbonate water beneath the alluvial fans, and becomes a briny sodium chloride water near the playa. Ground water near the playa exceeds Nevada drinking-water standards for $\mathrm{pH}$, dissolved solids, chloride, sulfate, and manganese. The high density of ground water beneath the playa could drive flow downward and away from the center of the basin. Ground water in Honey Lake basin and Smoke Creek Desert basin has similar stable-isotope composition, except near Sand Pass. If interbasin flow takes place, it most likely occurs at depths greater than 400 to 600 feet beneath Sand Pass or through volcanic rocks to the north.

High-altitude gaging stations measured a total of about 8 inches of precipitation during water year 1990. Streamflow records for part of 1989 and 1990 indicate that runoff in Smoke Creek fluctuated from peak flows of about 860 cubic feet per second during snowmelt events to zero flow in the summer as water was lost by infiltrating the alluvial fan. Total streamflow from Smoke Creek was about 4,400 acre-feet from December 1988 to September 1989 and about 1,300 acre-feet for water year 1990. Measurements of streamflow indicate that about 2,800 acre-feet of water per year discharged from volcanic rocks to streamflow, and a minimum of 7,300 acre-feet per year infiltrated and recharged unconsolidated sediments near Smoke, Buffalo, and Squaw Creeks. About 1,500 acre-feet was lost to evapotranspiration along the channel of Smoke Creek, and about 1,680 acre-feet of runoff 
from Smoke, Buffalo, and Squaw Creeks was probably lost to evaporation after a period of snowmelt on February 24, 1989.

\section{INTRODUCTION}

The Smoke Creek Desert basin is one of several potential water sources for the rapidly growing population of Reno, Sparks, and the unincorporated areas of Washoe County, Nev. A reconnaissance report by Glancy and Rush (1968) provided preliminary estimates of the ground-water budget for the basin; the estimates, however, were based on sparse information on surface water and on the few existing wells. Refining these estimates of ground-water flow and waterbudget components requires a more detailed hydrologic data base. Such a data base is the first step in making sound decisions about future development and allocation of water resources in the basin. To develop a data base that could serve as a basis for future studies of the Smoke Creek Desert basin, the U.S. Geological Survey, in cooperation with the California Department of Water Resources and the Regional Water Planning and Advisory Board-Reno-Sparks and Washoe County, collected hydrologic data in the basin between July 1988 and September 1990. Data collected are also published in Pupacko and others (1990, p. 271, 281, and 326) and in Bostic and others (1991, p. 289, 300, and 352-54).

\section{Purpose and Scope}

This report describes the hydrogeologic setting of the Smoke Creek Desert basin and presents and summarizes data collected in the basin between July 1988 and September 1990. Geophysical data were used to estimate the thickness of unconsolidated sediments along a profile across the center of the basin. Data were also collected on (1) surface-water flow of Smoke, Buffalo, Squaw, and Dry Creeks; (2) ground-water levels at 29 sites in the basin including sites near the boundaries of the basin; (3) fluctuations of water level, pressure head, flow rate, water temperature, and specific conductance in a network of 19 wells; (4) specific conductance and water temperature at about 50 wells and springs; (5) major- and minor-ion concentrations at 13 wells; (6) deuterium and oxygen-18 concentrations at 12 wells and springs in the Smoke Creek Desert basin compared with values measured in the Honey Lake basin; and (7) precipitation at two sites in water year 1990. (Water year is the 12-month period from October 1 to September 30, designated by the calendar year in which it ends.)

The data collected were used to estimate minimum values for components of the ground-water budget, such as recharge from infiltration of streamflow, runoff from perennial streams, and loss of streamflow to evapotranspiration. Measurements of stream discharge to identify reaches where channels were losing or gaining flow were used to infer ground-water levels relative to the stream channels. Estimates from previous studies were used along with water levels and geochemical data to evaluate current estimates of the direction of interbasin flow. The interpretation of the data collected on the geologic setting, hydrology, and geochemistry of the basin and inferences made on components of the water budget should be considered preliminary. The data in this study were collected during an extended dry period in northern Nevada.

\section{Acknowledgments}

The author thanks Brent and Vicki Espil, Jeanie Casey, and James Gibbons for allowing access to their private lands for data collection and Michael C. Widmar of Washoe County, Utility Division, for supplying hydrologic data.

\section{Water Use}

As of 1991, the Smoke Creek Desert basin is relatively undeveloped. Most of the land is used for grazing cattle and sheep, and abundant wildlife supports hunting for deer, antelope, and small game. Several windmills and numerous flowing wells provide small volumes of water for stock and wildlife. The most significant ground-water withdrawals occur at the Espil Ranch (fig. 1) where two wells are used to irrigate about 300 acres of alfalfa. Springs in the Granite Range provide about 200 acre-ft of water annually for the town of Gerlach. Surface-water flow of Smoke Creek is used to irrigate about 1,000 acres of native pasture. Surface-water flow of Squaw Creek is used to irrigate about 100 acres of native pasture and alfalfa. 


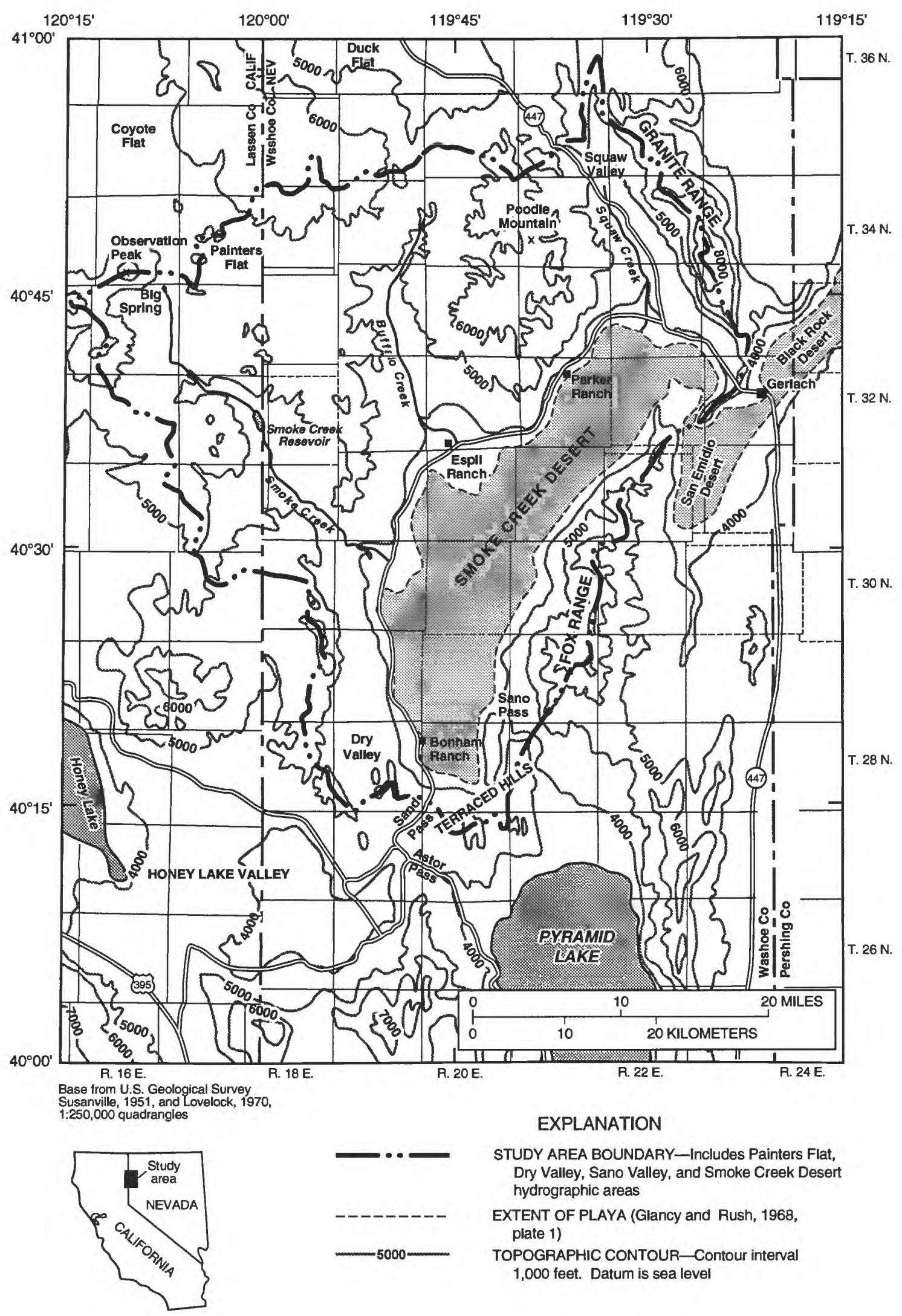

FIGURE 1.--Location of Smoke Creek Desert basin and the study area boundary. 


\section{Physiography}

The Smoke Creek Desert basin covers about $1,200 \mathrm{mi}^{2}$ (Glancy and Rush, 1968, p. 29-30) and is about $60 \mathrm{mi}$ north of Reno, Nev. About one quarter of the basin lies in California and about three quarters lies in Nevada (fig. 1). A large playa that covers most of the valley floor has an area of about $180 \mathrm{mi}^{2}$ (Glancy and Rush, 1968, table 11, p. 32) and an average altitude of about $3,900 \mathrm{ft}$ above sea level. A broad plateau dissected by surface-water drainages forms the west and north sides of the basin at an altitude ranging from 5,000 to $6,500 \mathrm{ft}$. The eastern boundary is formed by the Granite and Fox Ranges, which are relatively steep and narrow and rise to maximum altitudes of about 9,000 and $8,000 \mathrm{ft}$, respectively. In the gap between these two ranges, the Black Rock and San Emidio Deserts are connected to Smoke Creek Desert. The Terraced Hills form a low divide at the southern end of the basin, and low alluvial passes at the southwest (Sand Pass) and southeast (Sano Pass) corners of the valley floor connect the basin with Honey Lake and Pyramid Lake basins, respectively. The floor of Honey Lake Valley is about $100 \mathrm{ft}$ higher than the floor of Smoke Creek Desert basin, which is about $100 \mathrm{ft}$ higher than the altitude of Pyramid Lake.

\section{Climate}

Smoke Creek Desert basin lies in the rain shadow of the Sierra Nevada. These mountains are about 40 mi to the west of Smoke Creek Desert basin and effectively deplete winter storms of much of their moisture before they reach the basin. Most precipitation occurs from October through May, and December through March are the wettest months (Glancy and Rush, 1968, p. 18). Summer precipitation is limited to scattered thunderstorms. Average annual precipitation ranges from less than 6 in. on the valley floor to more than $20 \mathrm{in}$. along the crest of the Granite Range. Air temperatures in the basin range from about $100^{\circ} \mathrm{F}$ in July to $-20^{\circ} \mathrm{F}$ in January, and large diurnal fluctuations of as much as $50^{\circ} \mathrm{F}$ are common.

\section{HYDROGEOLOGIC SETTING OF BASIN}

Because there are no deep wells in the basin and no extensive geophysical surveys have been made, very little is known about the subsurface extent or hydrologic characteristics of geologic formations in the Smoke Creek Desert basin. However, inferences can be drawn from maps showing the surficial distribution of the formations and from detailed descriptions given in published geologic reports.

Two important hydrologic characteristics of a geologic formation are the volume of water the formation can hold--commonly called storage--and the rate water can move through the unit, which is determined by the permeability of the unit. Consolidated rocks generally store and transmit only small quantities of water, mainly through fractures. However, volcanic rocks commonly have rubble zones between flows and highly fractured porous zones that can store and transmit large quantities of water. Semiconsolidated deposits can store large quantities of water in pore spaces between sediment grains, but transmit water slowly because of partial cementation or compaction of pore spaces. Unconsolidated sediments also store water in pore spaces between sediment grains, and the quantity of water stored and transmitted increases with increasing grain size of the sediments. In the following descriptions of hydrogeologic units, storage and permeability have been combined in a descriptive term called the water-bearing capacity of the unit.

\section{Description of Hydrogeologic Units}

The geologic formations in the basin have been grouped into four hydrogeologic units based on their descriptions by Bonham (1969) and by Wagner and Saucedo (1993): (1) consolidated rocks, made up of metavolcanic and metasedimentary rocks of Permian and Triassic age and granitic rocks of Cretaceous age;

(2) volcanic rocks of Miocene and Pliocene age; (3) semiconsolidated deposits, mostly volcanic tuffs and lake sediments of Pliocene age; and (4) unconsolidated sediments (grouped as a single unit) that include Lake Lahontan sediments of Pleistocene age and alluvial-fan and playa deposits of Pleistocene and Holocene age. 


\section{Consolidated Rocks}

Metavolcanic and metasedimentary rocks of Permian and Triassic age crop out within the basin in a small exposure on the west side of the valley floor, in the northernmost part of the Granite Range, and in the Fox Range (pl. 1). The metavolcanic rocks are basalts, andesites, flow breccias, and tuffs (Bonham, 1969, p. 5 and 6). The metasedimentary rocks in the Fox Range are several thousand feet thick and are composed of slate, phyllite, quartzite, and schists along with recrystallized limestones, limestone conglomerates, and dolomite that are more than several hundred feet thick. The unit probably has low water-bearing capacity, except where fractured or where solution features in limestone could make the unit moderately water bearing.

The bulk of the Granite Range in Smoke Creek Desert basin is composed of Cretaceous intrusions of granodiorite. Granodioritic intrusive rocks are also exposed on the west side of the valley floor and in the Fox Range (pl. 1). In the Granite Range, they have been dated at about 88 million years old, which is similar in age to granites of the Sierra Nevada batholith (Bonham, 1969, p. 9). Bonham (1969, p.49) noted that the granodiorite in the northern part of the Fox Range is pervasively foliated (incipient fractures). These rocks have low water-bearing capacity; fractures or foliation probably make the unit only slightly more water bearing.

The metamorphic and granitic rocks described above are generally impermeable to ground-water flow. They form a distinct ground-water divide along the east side of the basin, and they probably underlie most of the Smoke Creek Desert basin, forming the lower limit for most ground-water flow in the basin. Away from the areas of outcrop, however, the depth at which these metamorphic and granitic rocks might lie below land surface is not known. Gravity data interpreted by Jachens and Moring (1990, pl. 2, p. 8) show consolidated rocks at a depth of more than $3,000 \mathrm{ft}$ below land surface in the northwest corner of the basin, although the authors state that the estimate is probably too small. Further geophysical work is needed to obtain estimates of the depth to these rocks beneath the entire basin.

\section{Volcanic Rocks}

Volcanic rocks of Miocene and Pliocene age cover the west half of the Smoke Creek Desert basin, and they are also exposed at an isolated knob near the center of the playa east of Smoke Creek, in the southern end of the Fox Range, and in the Terraced Hills (pl. 1). In the northern, western, and southern parts of the basin, volcanic rocks are composed of basalt and andesite flows (Wagner and Saucedo, 1993; and Bonham, 1969, p. 20). In the Fox Range, volcanic rocks are composed of late Miocene basalt, andesite, and dacite flows (Bonham, 1969, p. 29). The volcanic rocks are more than $1,000 \mathrm{ft}$ thick near Poodle Mountain (Bonham, 1969, p. 21), and gravity data (Jachens and Moring, 1990, pl. 2) indicate a thickness of at least $3,000 \mathrm{ft}$ in the northwest part of the basin. The tops and bottoms of individual flows have rubble zones, and columnar jointing is common (Bonham, 1969 , p. 21); consequently, these rocks are probably moderately to highly water bearing. The numerous springs on the west side of the basin indicate welded, impermeable zones in the volcanic rocks that cause localized, perched water tables within the unit.

Few wells in the Smoke Creek Desert basin tap volcanic rocks to any significant depth; however, volcanic rocks of similar composition are an important aquifer on the east side of the Honey Lake basin (Handman and others, 1990, p. 8). Thus, the volcanic rocks in the Smoke Creek Desert basin could form a previously unrecognized aquifer on the north, west, and south sides of the basin and to an unknown extent beneath the valley floor. The outcrop pattern of volcanic rocks indicates that they underlie much of the west side of the valley floor. The unit receives recharge from precipitation and infiltration of streamflow; it could provide an avenue for recharge from the western mountain blocks to volcanic rocks beneath the valley floor and to unconsolidated sediments filling the center of the basin. The permeable volcanic rocks that separate Smoke Creek Desert basin, Honey Lake basin, and Pyramid Lake basin are also found along the northern, western, and southern boundaries of Smoke Creek Desert basin, increasing the potential for interbasin ground-water flow. 


\section{Semiconsolidated Deposits}

Tuffaceous deposits of Pliocene age crop out on the west side of the basin and are interbedded with volcanic rocks of the same age (Wagner and Saucedo, 1993 and Bonham, 1969, p. 15-16). The semiconsolidated deposits are ash-flow, ash-fall, water-lain, and water-reworked tuffs of silt and clay that become coarser toward the base of the unit. The thickness of these deposits ranges from 0 to $1,200 \mathrm{ft}$ (Bonham, 1969 , p. 15), and the outcrop pattern indicates that they could be widespread on the west side of the basin. The unit is poorly water bearing and probably forms a barrier to ground-water flow between overlying and underlying volcanic rocks. Away from outcrop locations, however, little is known about the thickness and areal extent of semiconsolidated deposits or their effect on ground-water movement.

Glancy and Rush (1968, p. 11) suggest that semiconsolidated lake sediments of Tertiary age make up a major part of the basin fill underlying unconsolidated sediments beneath the valley floor. The depth to the Tertiary lake deposits, their thickness, and relation to the Pliocene deposits within the volcanic section are not known.

\section{Unconsolidated Sediments}

Alluvial deposits of stream sediments and alluvial-fan sediments surround the valley floor and are of Pleistocene and Holocene age. They consist of well-sorted to poorly sorted mixtures of boulders, gravel, sand, silt, and clay. The sediments range in thickness from less than $1 \mathrm{ft}$ where they overlie consolidated rocks to possibly as much as $500 \mathrm{ft}$ near the base of the volcanic plateau on the west side of the basin. How far these sediments extend toward the playa on both the west and east sides of the basin is not known. The alluvial sediments have moderate to high water-bearing capacity and are the source for most ground water pumped in the basin. They also are recharged from infiltration of streamflow and groundwater flow from adjacent mountain blocks or through underlying volcanic rocks. On the middle to lower slopes of the alluvial deposits, ground water is discharged by phreatophytic vegetation.

Unconsolidated sediments near the playa in the Smoke Creek Desert basin are dominated by recent playa deposits and lake deposits of prehistoric Lake Lahontan, which inundated much of western Nevada during late Pleistocene time. Benson and Thompson (1987, p. 75 and 78) show that a lake was present in the Smoke Creek-Black Rock Desert about 45,000 yr ago, and it reached its highest stand about $13,500 \mathrm{yr}$ ago at an altitude of about $4,365 \mathrm{ft}$--almost $500 \mathrm{ft}$ above the present altitude of the valley floor. Benson and Paillet (1989, p. 273) also show that a high stand of Lake Lahontan in Smoke Creek Desert basin 20,000 to 25,000 yr ago could have been caused by diversion of the Humboldt River through the Black Rock and Smoke Creek Deserts and into Pyramid Lake. Deposits of Lake Lahontan and Holocene playa sediments are mostly fine grained with thin veneers of well-sorted beach deposits around the margin of the valley floor. The thickness of the fine-grained deposits is not known, but they have low water-bearing capacity and the beach deposits are mostly unsaturated. If the Humboldt River did flow through the Smoke Creek Desert basin, coarse-grained fluvial deposits could be present as stringers within the finer grained lake deposits. The coarser grained fluvial sediments could be moderately to highly water bearing, but it is not known where or to what extent they interfinger with the Lahontan and recent playa sediments. The sediments in the center of the valley floor probably receive recharge from the alluvial deposits, possibly from underlying volcanic rocks, and from flooding of the playa after runoff events. Ground water is discharged through the finegrained sediments by phreatophytic vegetation and evaporation from bare soil.

\section{Geophysical Model}

The shape and extent of the hydrogeologic units in Smoke Creek Desert basin--such as the depth to volcanic rocks and their extent beneath the west side of the valley floor--are an important control on the hydrologic flow system of the basin. The volcanic knob east of Smoke Creek exposed near the center of the playa (pl. 1) is evidence that volcanic rocks could be close to the surface beneath the west side of the playa. In this study, geophysical methods provided preliminary estimates of the depth to volcanic rocks along a profile across the center of the basin. A magnetometer was used to measure the intensity of the earth's magnetic field along the profile at 1,000- to 2,000-ft intervals. The intensity of the field is determined by the depth of magnetic bodies and their magnetic susceptibility. Seismic refraction soundings gave independent 
estimates of the depth beneath the Smoke Creek alluvial fan to high-velocity material, which is assumed to be volcanic rocks.

Two seismic refraction soundings and 71 magnetic measurements were made from northwest to southeast across the playa (pl. 1). The magnetic profile A-A' was used in a computer program developed by Webring (1985) to estimate the depth to volcanic rock beneath the playa. The program calculates the theoretical magnetic profile that results from a hypothetical model of the magnetic bodies along the profile. The geometry and magnetic susceptibility of the bodies can be adjusted until the calculated magnetic profile approximates the measured magnetic profile. A shorter, second profile was made (B-B', pl. 1) south of $\mathbf{A}-\mathbf{A}^{\prime}$ to determine if features shown in profile $\mathbf{A}-\mathbf{A}^{\prime}$ extend in a north-south direction.

The surface outcrop of geologic units and the depths to volcanic rock obtained from the seismic refraction soundings constrain the hypothetical model shown in figure 2. To reduce edge effects in model calculations, the model is extended several thousand feet beyond the profile of measurements. Magnetic susceptibility of the bodies was adjusted within reasonable limits until the depth to volcanic rock matched that obtained by the seismic soundings. Final values are within limits published by Lindsley and others (1966, p. 548). The model is not unique; a model with different geometries and different magnetic susceptibilities could produce a similar fit to the measured magnetic profile. The model is also limited by assuming that the bodies have uniform magnetic susceptibilities throughout. This assumption could cause errors in depth estimates away from the points of constraint.

Results of model calculations (fig. 2) indicate a buried pediment about $500 \mathrm{ft}$ deep beneath the upper part of the Smoke Creek alluvial fan, and the depth to volcanic rocks increases to about $2,000 \mathrm{ft}$ beneath the playa. Measurements indicate that the volcanic knob near the center of the playa could be a narrow volcanic vent (fig. 2) centered in a downfaulted block. Magnetic intensity along profile B-B' shows no indication of near-surface volcanic rocks. Measurements east of the knob along profile $\mathbf{A}-\mathbf{A}^{\prime}$ indicate the depth to volcanic rock is also about $2,000 \mathrm{ft}$ near the center of the basin. The decrease in magnetic intensity on the east end of the profile was modeled by extending sedimentary rocks of low susceptibility (body 3 in fig. 2), which were mapped in the Fox Range, to beneath the playa. An equally valid model that would accommodate the lower magnetic intensity would be to increase the estimated depth to volcanic rocks near the eastern edge of the playa. Further seismic refraction soundings need to be made or test holes drilled to confirm the estimated depths and rock types used in the model.

\section{Structural Framework}

The Smoke Creek Desert is in a zone of complex, deeply seated crustal movement that has continued since Jurassic time. Movement along shear zones has created the basin and defined the geometry and boundaries of aquifers. Sediments filling the basin mask details of the geologic structure, as well as the lateral and vertical extent of hydrogeologic units beneath the valley floor. How structural faulting affects groundwater movement in the basin, beyond defining the shape and extent of the aquifers, is not known.

Three geologic and physiographic features bound the Smoke Creek Desert basin: (1) the Modoc Plateau (Macdonald, 1966) on the west and north sides, characterized by volcanic cones surrounded by relatively flat-lying volcanic flows; (2) the Basin and Range Province on the east side, characterized by elongate basins surrounded by elevated mountain blocks; and (3) the Walker Lane on the south side, a regional northwest-trending fault system that extends from Las Vegas, Nev., to the south end of the Smoke Creek basin (fig. 3). The fault system has mainly right-lateral offset similar to and parallel to those of the San Andreas fault system in California (Bonham, 1969, p. 45).

Deformation that formed the topography of the Smoke Creek Desert basin began in middle to late Tertiary time and is continuing (Bonham, 1969, p. 42). Along with this deformation, volcanism in Pliocene time built the plateau on the northwest side of the basin (Bonham, 1969, p. 43).

The Modoc Plateau encompasses the western half of the Smoke Creek Desert basin (Bonham, 1969, p. 48). The plateau is bounded by numerous Pleistocene to recent north- to northwest-trending faults. However, deformation of the plateau as a whole has been minimal since Miocene time (Bonham, 1969, p. 47). 

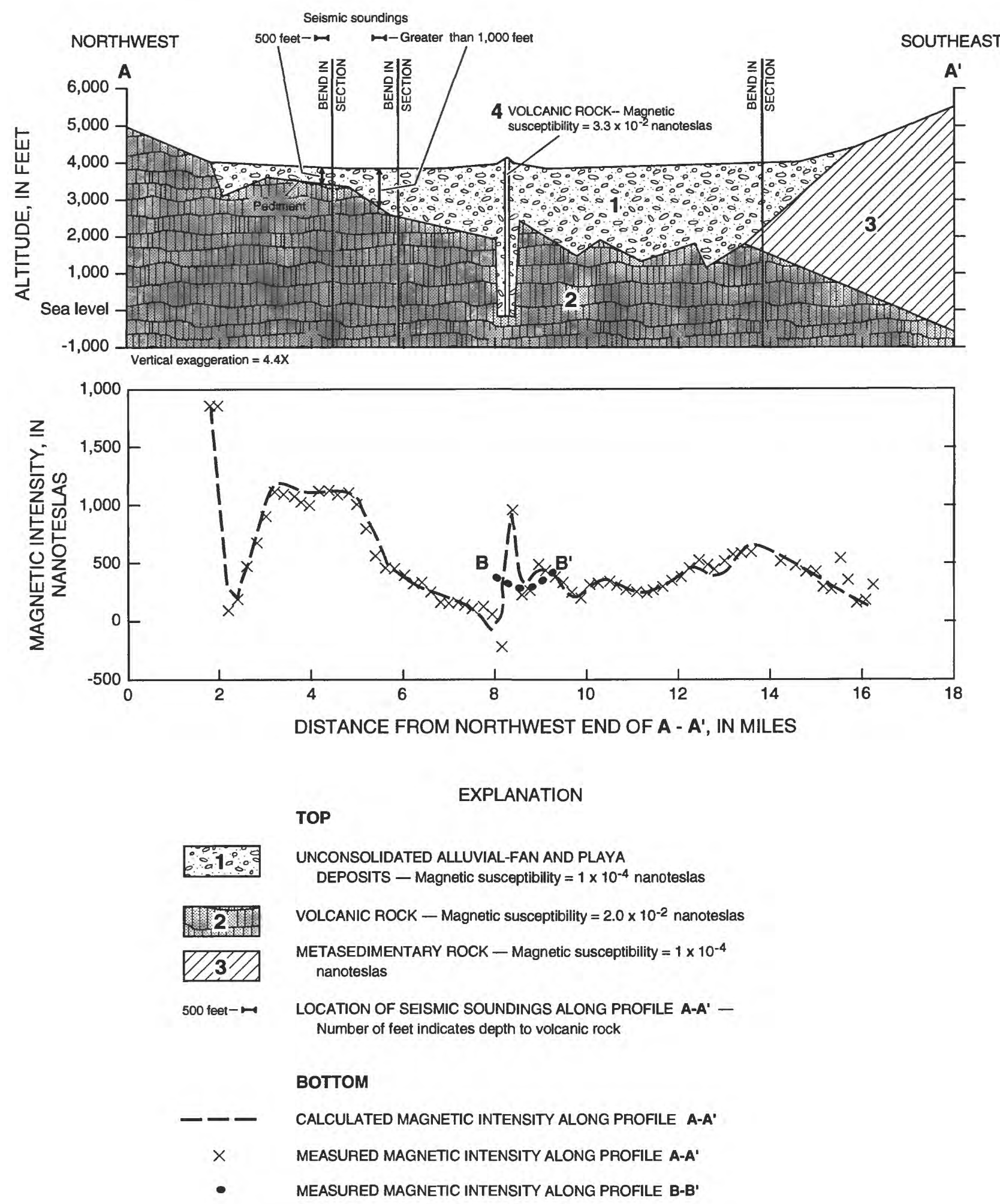

FIGURE 2.--Top --Cross section showing hypothetical subsurface distribution of geologic units for which calculated magnetic profile closely resembles measured profile.

Bottom--Cross section showing measured and calculated magnetic profiles for $\mathbf{A}-\mathbf{A}^{\prime}$ and measured magnetic profile for B-B'. (See plate 1 for location of profiles.) Magnetic intensity (nanoteslas) is relative to an arbitrary datum. Seismic soundings show location of depth control for model. 


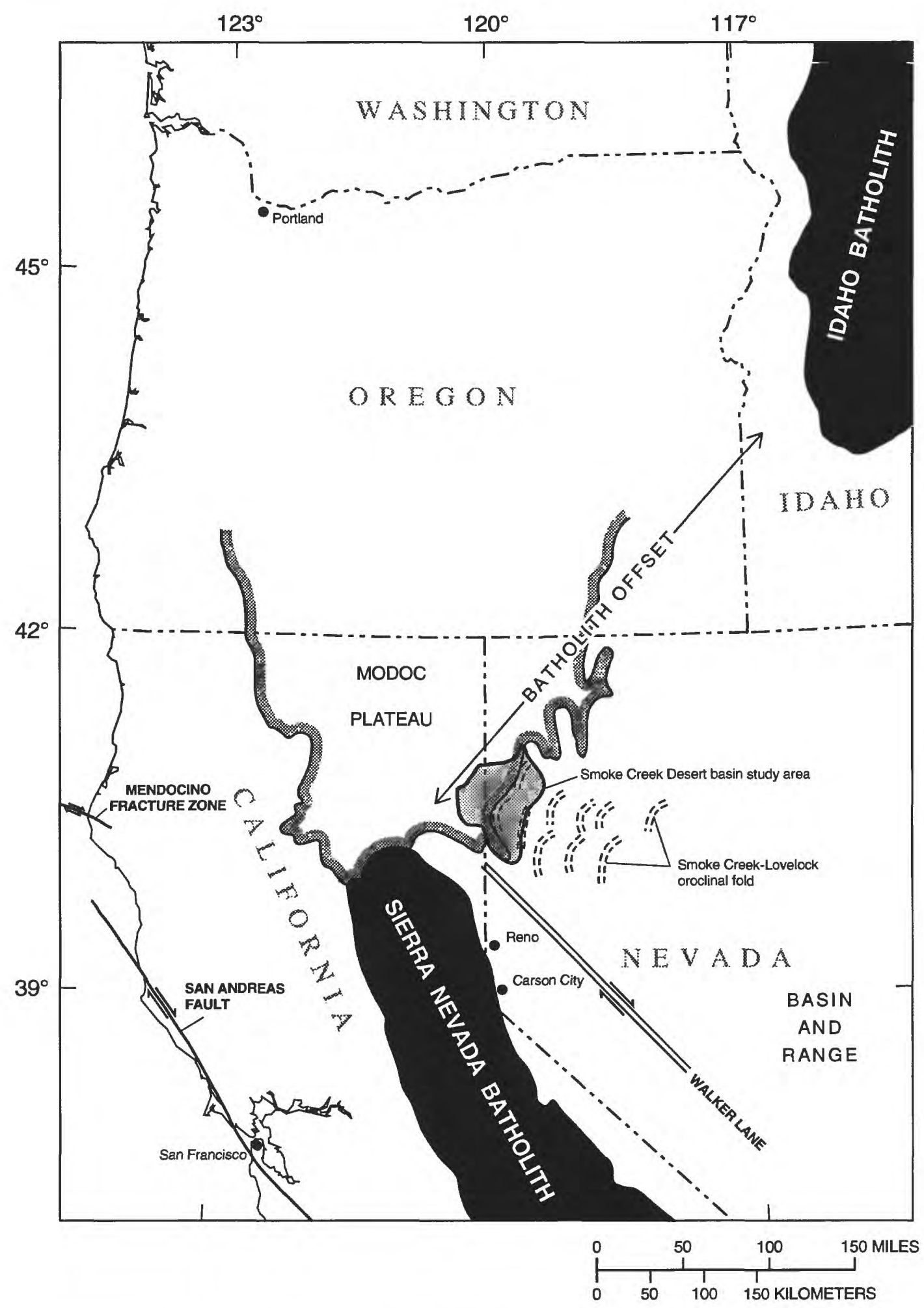

FIGURE 3.-- Relation of Smoke Creek Desert basin to physiographic and geologic features: Modoc Plateau, Sierra Nevada, and Basin and Range Province. Geologic features from Sales (1966, plates 2, 5, and 14) and Wise (1963, fig. 2). 
In contrast to the western half of the basin, the eastern half shows structural features characteristic of the Basin and Range Province: downfaulted blocks beneath the valley floor and uplifted mountain blocks bound the basin. The eastern edge of the Modoc Plateau ends along normal faults of Pleistocene to Holocene age on the west side of the valley floor with offsets of up to several hundred feet (Bonham, 1969, p. 48). The Granite Range mountain block is uplifted a minimum of $4,200 \mathrm{ft}$ on its west side along northwest-trending faults that have only dip-slip movement (Bonham, 1969, p. 48). The Fox Range is concave to the east and is tilted to the east as much as $30^{\circ}$ along high-angle faults on the west side of the range with "several thousand feet of dip-slip displacement" (Bonham, 1969, p.49).

Basin-and-range structure is thought to originate from extension of the earth's crust by movement along broad, northwest-trending shear zones with right-lateral offset (Shawe, 1965, p. 1362; Wise, 1963, p. 362; Sales, 1966; Albers, 1967, p. 151; and Stewart, 1988, p. 705). Shear zones are probably deeply seated-lying in the upper mantle and lower part of the crust - and result in basin-and-range block faulting in the more brittle, upper part of the crust (Shawe, 1965, p. 1369). Movement along the shear zones has taken place since early Jurassic time (Albers, 1967, p. 153), and the Walker Lane forms the southwest boundary of the shear zone (Wise, 1963, p. 358).

Major tectonic features intersect near the Smoke Creek Desert (fig. 3). Wise (1963, p. 358) describes offset of batholiths of the Sierra Nevada and of batholiths in central Idaho by 300 to $400 \mathrm{mi}$ along a northeast trend with a right-lateral displacement. The offset lies along the northwest side of the Smoke Creek Desert where the trend of the Mendocino fracture zone intersects the Walker Lane (Wise, 1963, p. 359). Sales (1966, pl. 2) also noted a bend in crustal structure forming an eastward concavity in the shape of mountain ranges from Smoke Creek Desert to Lovelock, Nev. (fig. 3). He calls this area the Smoke CreekLovelock oroclinal fold and believes the Smoke Creek Desert basin represents a major strike-slip fault deformed by oroclinal (large-scale) folding (Sales, 1966, p. 116).

Because of the large-scale and complex movement in the structural setting of the Smoke Creek Desert, the depth to consolidated rocks beneath the western part of the basin and the extent and the depth to volcanic rocks beneath the playa are difficult to estimate without geophysical surveys confirmed by test drilling.

\section{DISTRIBUTION OF PRECIPITATION}

Annual precipitation in the Smoke Creek Desert basin ranges from less than $6 \mathrm{in} / \mathrm{yr}$ on the valley floor to more than $20 \mathrm{in} / \mathrm{yr}$ near the top of the Granite Range. Two maps of the distribution of precipitation over the basin have been published: one covering California and part of the Nevada side of the basin (California Department of Water Resources, 1963, pl. 2), and one covering only the Nevada side of the basin (Hardman, 1965). The distribution for the entire basin is shown in figure 4 where Hardman's map was used for the Granite and Fox Ranges and the California Department of Water Resources map was used for the remainder of the basin. In a study of the Honey Lake basin, Handman and others (1990 p. 18) used data collected from 1963 to 1988 and, on the basis of those data, added 2 in. of precipitation to each contour on the California Department of Water Resources map. The lack of data in the Smoke Creek Desert does not allow the same adjustment.

Two storage precipitation gages were installed in the Smoke Creek Desert basin to collect precipitation data at altitudes above the valley floor: one near Observation Peak on the west side of the basin at an altitude of about $5,000 \mathrm{ft}$, and one near Poodle Mountain on the north side of the basin at about $6,000 \mathrm{ft}$ (fig. 4). The gages are $1 \mathrm{ft}$ in diameter by $8 \mathrm{ft}$ high and are equipped with a wind baffle. They are initially charged with ethylene glycol to prevent freezing and topped by a layer of oil to prevent evaporation. Readings are made as near as possible to October 1 to provide a measurement of total precipitation for the water year. Total precipitation for the 1990 water year (October 1, 1989 to September 30, 1990) was 8.16 in. at the Observation Peak gage and 8.28 in. at the Poodle Mountain gage (table 1). These values are comparable to amounts measured at the Espil Ranch and Gerlach stations located on the valley floor; both of these valley stations had less than 9 days of missing data during the winter months in water year 1990. 


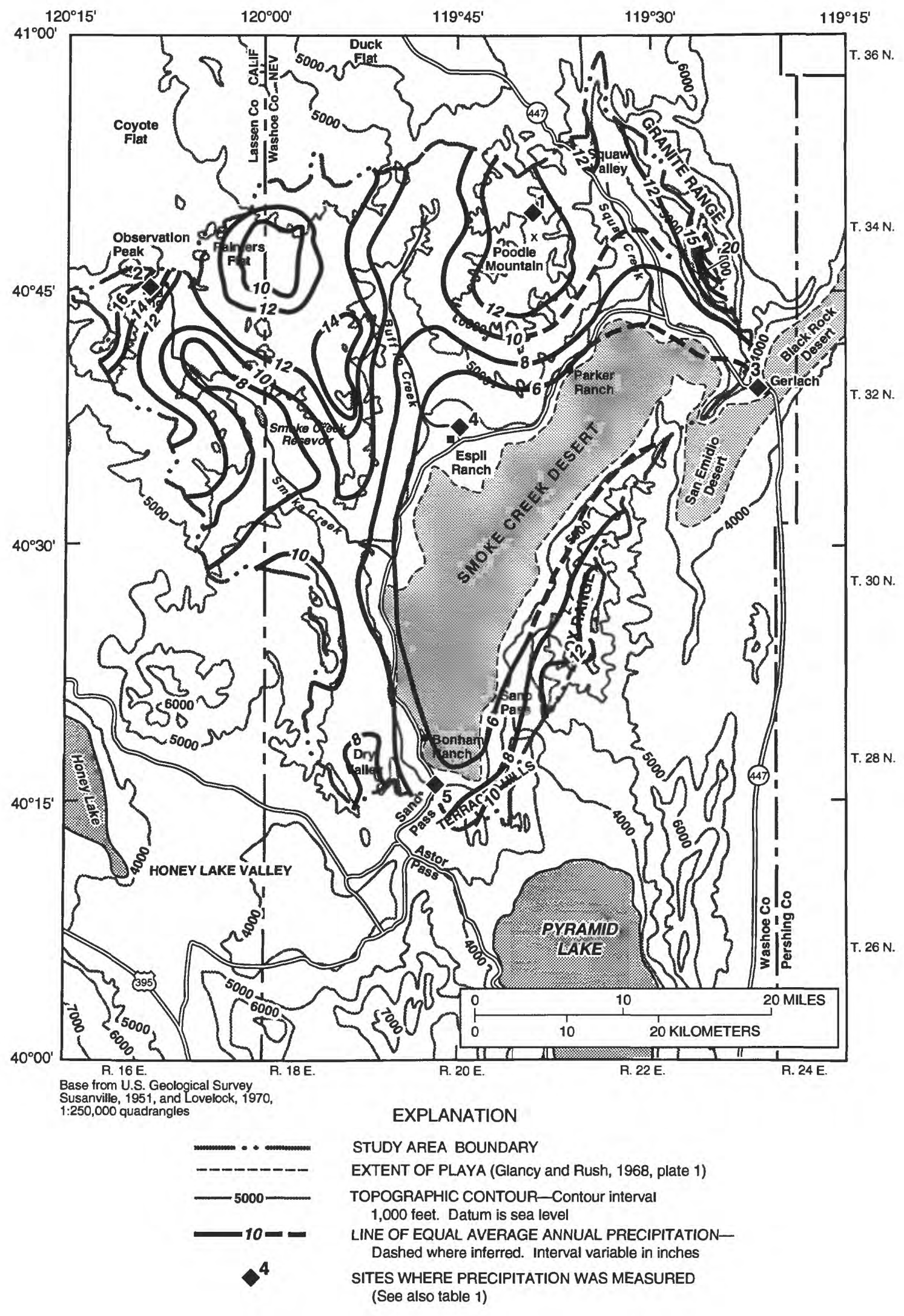

FIGURE 4.--Distribution of average annual precipitation in Smoke Creek Desert basin. [Modified from Hardman (1965) and from California Department of Water Resources (1963).] 
For a general comparison, table 1 includes the long-term average precipitation at Gerlach and Sand Pass for the calendar year. The values indicate that, at least at the lower altitudes, both maps used to construct figure 4 are fairly accurate. However, both stations lack data for the early 1980 's, which were the wettest years on record for northern Nevada. Continued data collection is required to more accurately map the distribution of precipitation.

\section{STREAMFLOW}

\section{Smoke Creek}

Data on surface water were collected at 24 sites (figs. 6 and 8). A gage recording streamflow hourly was installed at Smoke Creek on December 15, 1988, and operated through the 1990 water year. Tables of daily mean flow at the gage are published in Pupacko and others (1990, p. 271) and Bostic and others (1991, p. 289). Streamflow at the gage was highly variable and ranged from a peak flow of about $860 \mathrm{ft}^{3} / \mathrm{s}$ on February 24, 1989 (Pupacko and others, 1990, p. 271), to zero flow during summer months (fig. 5). The runoff on February 24 was caused by a melting snowpack as daytime temperatures rose to nearly $60^{\circ} \mathrm{F}$. Streamflow averaged about $8 \mathrm{ft}^{3} / \mathrm{s}$ during the 1989 water year; flow was zero from July 6 through September 30 . Total streamflow for the 10 months that the gage operated in water year 1989 was about 4,400 acre-ft. During the 1990 water year, the channel was dry from October 1 through October 25, and streamflow averaged about $4 \mathrm{ft}^{3} / \mathrm{s}$ from November through April. The channel was dry from May 5 through September 30 except for runoff from thunderstorms in July. Total streamflow for water year 1990 was about 1,300 acre-ft.

TABLE 1. Precipitation data for Smoke Creek Desert stations

\begin{tabular}{|c|c|c|c|c|c|c|}
\hline $\begin{array}{c}\text { Site } \\
\text { number } \\
\text { (fig. 4) }\end{array}$ & Location & $\begin{array}{c}\text { Latitude } \\
\text { longitude } \\
\text { (deg, } \mathrm{min}, \mathrm{sec} \text { ) }\end{array}$ & Station type $e^{a}$ & $\begin{array}{c}\text { Altitude } \\
\text { (feet) }\end{array}$ & Water year & $\begin{array}{l}\text { Precipitation } \\
\text { (inch) }\end{array}$ \\
\hline 1 & Poodle Mountain & $\begin{array}{c}40^{\circ} 51^{\prime} 42^{\prime \prime} \\
119^{\circ} 39^{\prime} 28^{\prime \prime}\end{array}$ & Storage gage (USGS) & 6,050 & 1990 & 8.28 \\
\hline 2 & Observation Peak & $\begin{array}{c}40^{\circ} 49^{\prime} 23^{\prime \prime} \\
120^{\circ} 08^{\prime} 47^{\prime \prime}\end{array}$ & Storage gage (USGS) & 5,480 & 1990 & 8.16 \\
\hline 3 & Gerlach & $\begin{array}{c}40^{\circ} 39^{\prime} 00^{\prime \prime} \\
119^{\circ} 21^{\prime} 00^{\prime \prime}\end{array}$ & Daily observation (NOAA) & 3,950 & $\begin{array}{c}1990 \\
1989 \\
1988 \\
\text { Long-term average }\end{array}$ & $\begin{array}{r}{ }^{b} 8.15 \\
8.09 \\
b_{5} 5.32 \\
{ }^{c} 6.09\end{array}$ \\
\hline 4 & Espil Ranch $^{\mathrm{d}}$ & $\begin{array}{c}40^{\circ} 37^{\prime} 00^{\prime \prime} \\
119^{\circ} 45^{\prime} 00^{\prime \prime}\end{array}$ & Daily observation (NOAA) & 3,850 & $\begin{array}{l}1990 \\
1989 \\
1988\end{array}$ & $\begin{array}{l}b_{5.24} \\
e_{6.97} \\
e_{3.94}\end{array}$ \\
\hline 5 & Sand Pass & $\begin{array}{l}40^{\circ} 19^{\prime} 00^{\prime \prime} \\
119^{\circ} 48^{\prime} 00^{\prime \prime}\end{array}$ & Daily observation (NOAA) & 3,900 & Long-term average & $f_{6.58}$ \\
\hline
\end{tabular}

${ }^{a}$ USGS, data collected by U.S. Geological Survey; NOAA, data collected by National Oceanic and Atmospheric Administration.

bess than 9 days of data missing.

'Period of record: calendar years 1913-49, 1951-57, 1963-72, 1986-90.

${ }^{\mathrm{d}}$ Total period of record at this site: water years $1988-90$.

${ }^{\mathrm{e}}$ More than 9 days of data missing.

f Period of record: calendar years 1914-62, 1967-70. 
The drainage of Smoke Creek can be divided into 5 reaches on the basis of geomorphology near the stream channel (fig. 6): (1) an upper reach draining a subbasin of volcanic rocks (sites 7-12); (2) an upper canyon reach where streamflow incised a canyon 200 to $300 \mathrm{ft}$ deep into the volcanic rocks, and a small dam at the canyon head forms Smoke Creek Reservoir (sites 12-17); (3) a middle reach draining a sub-basin of alluvium covered with meadow grasses (sites 17-20); (4) a lower canyon reach where streamflow incised as much as 1,000 ft into volcanic rocks (sites 20-21); and (5) a lower reach where streamflow crosses an alluvial fan and flows onto the west side of the Smoke Creek Desert playa (sites 21-23).
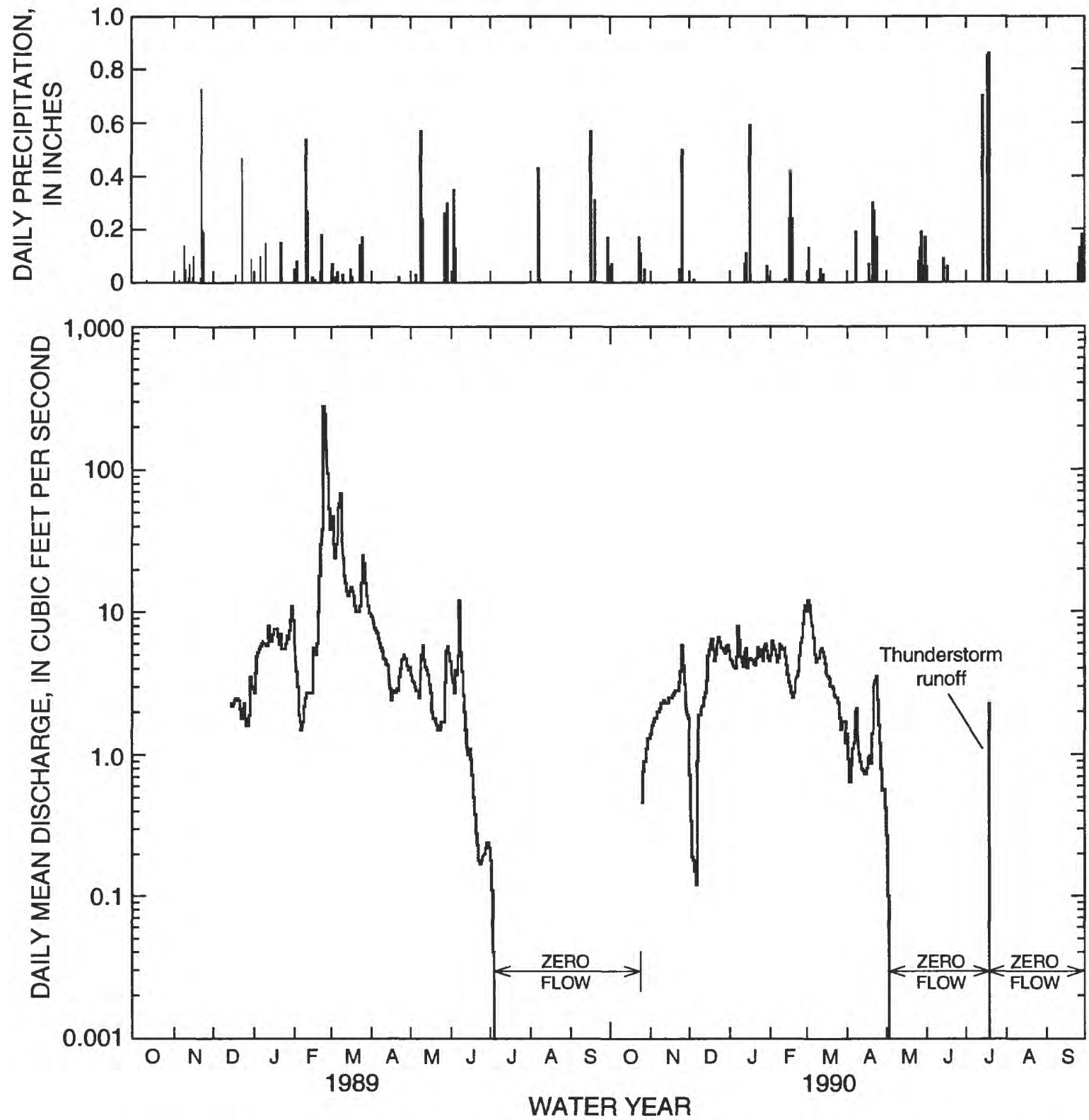

FIGURE 5.--Daily mean precipitation recorded at Espil Ranch (site 4 in figure 4) and daily mean streamflow of Smoke Creek (site 22 in figure 8), water years 1989 and 1990. 


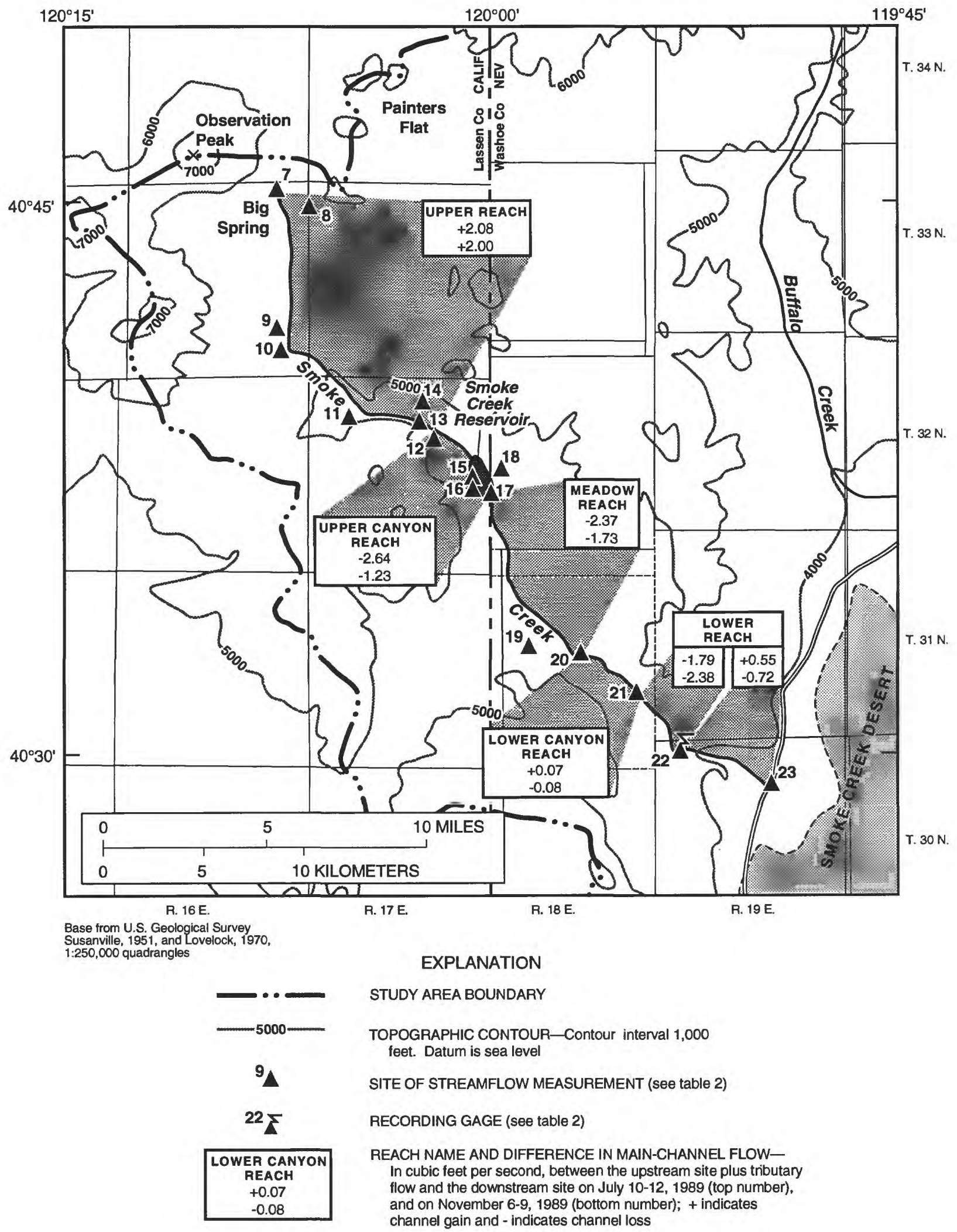

FIGURE 6.--Location of miscellaneous streamflow measurements and amount of channel loss or gain along five reaches of Smoke Creek in July and November 1989. 
Streamflow measurements along Smoke Creek were made in mid-July and early November of 1989 to determine (1) water lost to evapotranspiration and (2) areas of recharge and discharge (table 2, sites 7-23). Both sets of measurements represent base-flow conditions. Mid-July measurements represent conditions during maximum evapotranspiration by rabbitbrush and willow (Robinson, 1970, p. D26)--both hardy phreatophytes along the channel of Smoke Creek. Early November measurements represent conditions after evapotranspiration has ceased for the season. Robinson (1970, p. D25) reports that after air temperature drops to $28^{\circ} \mathrm{F}$, rabbitbrush and willow stop growing. Figure 7 shows that the minimum temperature at Espil Ranch dropped well below $28^{\circ} \mathrm{F}$ after October 28, 1989. With the preceding extended dry conditions, precipitation of 0.17 and 0.11 in. on
October 24 and 25, 1989 (fig. 5) was probably not sufficient to raise streamflow and affect November measurements. This assumption is further supported by the fact that greater precipitation in September 1989 did not produce streamflow. Therefore, the difference between mid-July and early November measurements is assumed to be an indicator of the water lost to stream-channel evapotranspiration during the growth season.

Differences in streamflow between adjoining reaches of the creek indicate gaining or losing reaches. Reaches where streamflow was lost provided recharge to the underlying aquifer and the water table is lower than the streambed. Areas where streamflow was gained indicate that the underlying aquifer was discharging to the stream, and the water table may be at or above the streambed.

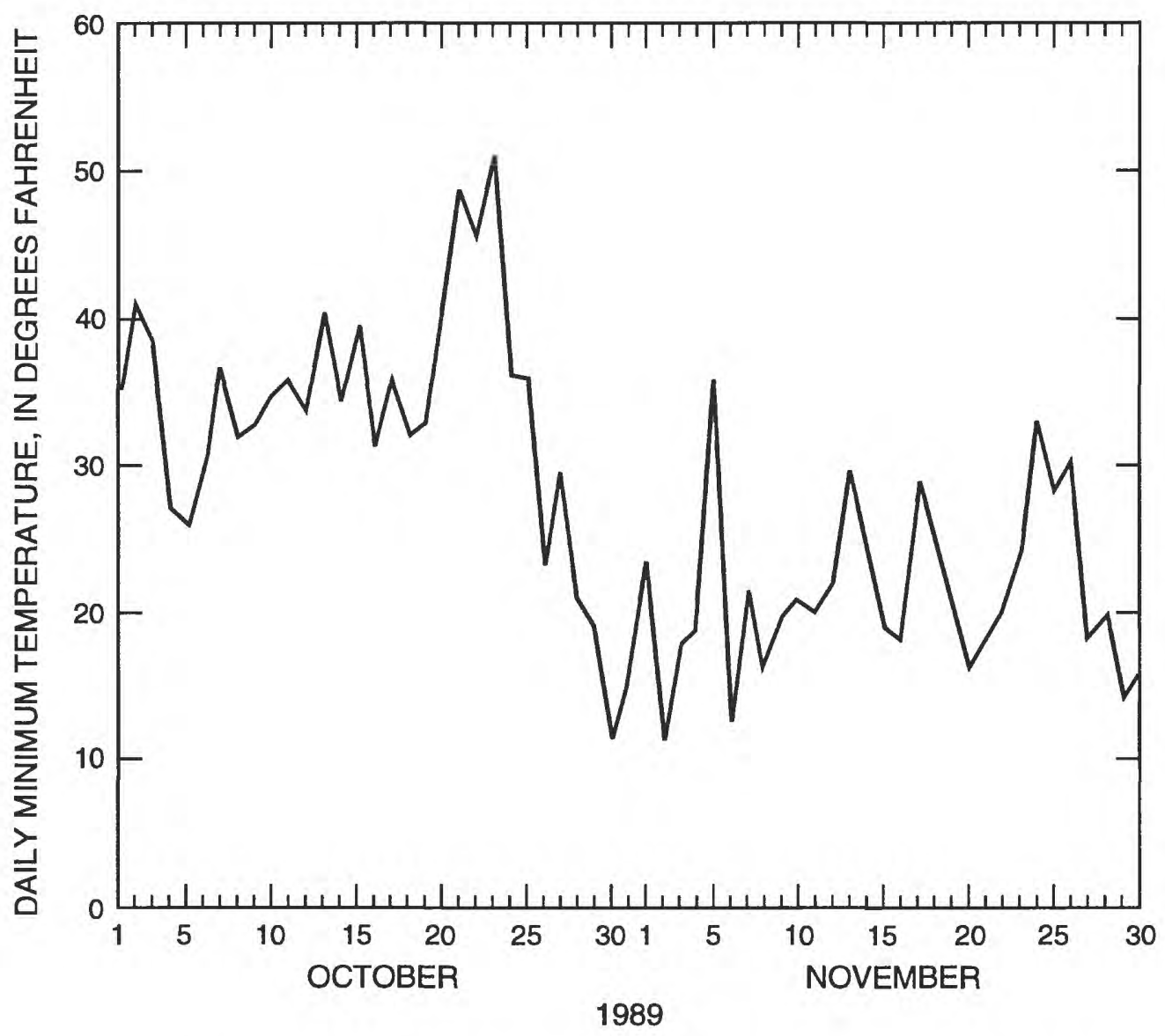

FIGURE 7.--Daily minimum temperature at Espil Ranch during October and November 1989 (data from National Climatic Center). 


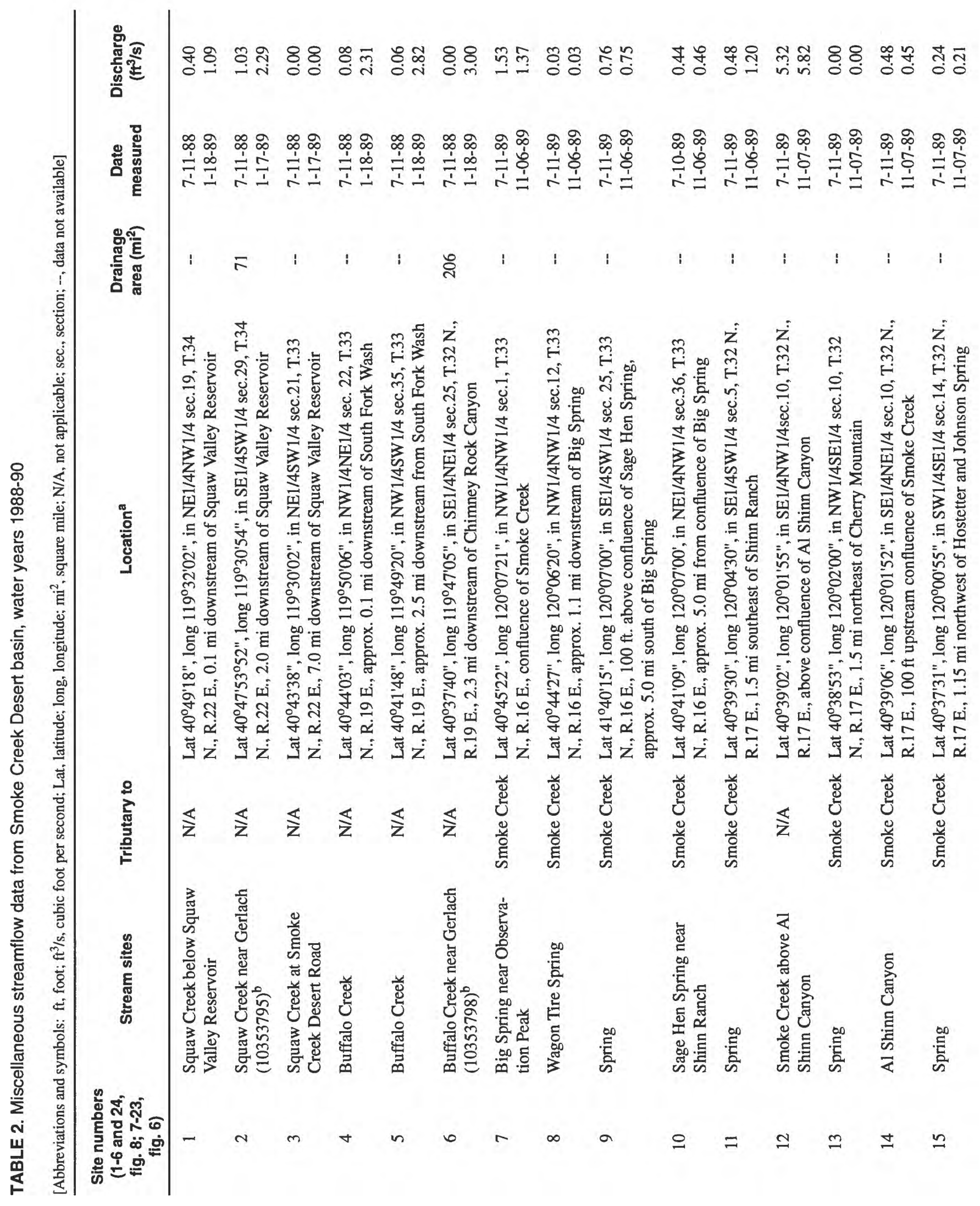




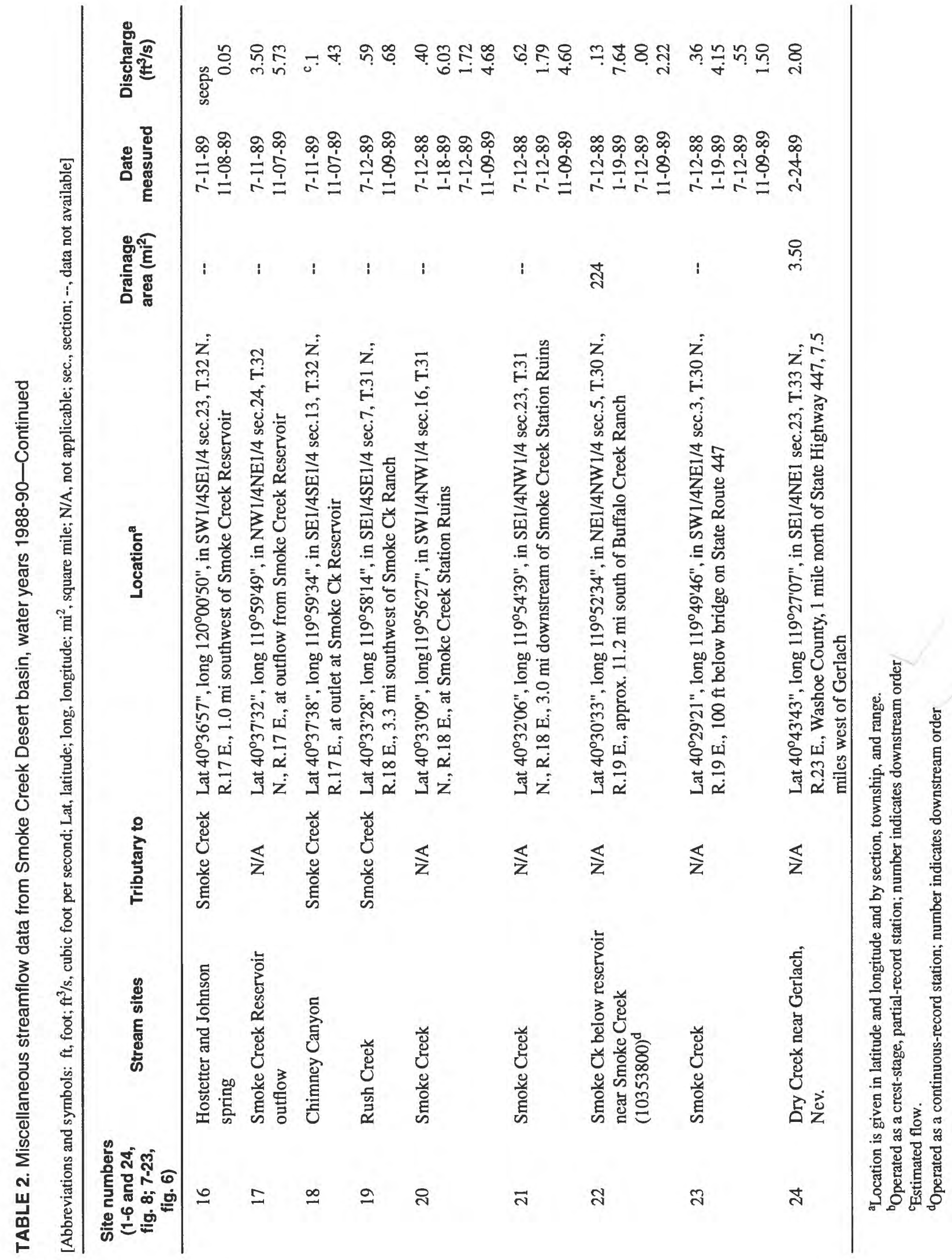


Streamflow measurements show that the upper reach of Smoke Creek gained about $2 \mathrm{ft}^{3} / \mathrm{s}$ from ground-water seepage in July with little change in November. These measurements indicate that groundwater levels in the adjacent volcanic rocks were above the altitude of the streambed and that evapotranspiration losses were minimal in that reach. An altitude of about $5,000 \mathrm{ft}$ is estimated for water levels in the volcanic rocks adjacent to the stream between stations 10 and 11 along this reach.

Streamflow through the upper canyon reach showed a loss of about $2.6 \mathrm{ft}^{3} / \mathrm{s}$ in July and $1.2 \mathrm{ft}^{3} / \mathrm{s}$ in November. The difference, about $1.4 \mathrm{ft}^{3} / \mathrm{s}$, is an estimator of the evapotranspiration loss from phreatophyte growth (dense willows) in the canyon. The loss of $1.2 \mathrm{ft}^{3} / \mathrm{s}$ in November shows that infiltration of streamflow recharged adjacent aquifers through this reach.

Through the meadow reach, measurements showed a loss of $2.4 \mathrm{ft}^{3} / \mathrm{s}$ in July and $1.7 \mathrm{ft}^{3} / \mathrm{s}$ in November, indicating an estimated evapotranspiration loss in July of about $0.7 \mathrm{ft}^{3} / \mathrm{s}$. Infiltration of $1.7 \mathrm{ft}^{3} / \mathrm{s}$ recharged unconsolidated sediments through this reach.

Streamflow in the lower canyon reach showed little significant gain or loss in either July or November. Evapotranspiration loss seems minimal in the reach, and either the volcanic rocks through that reach are relatively impermeable or ground-water levels in the adjacent volcanic rocks were equal to the altitude of the streambed.

As the stream flows onto the alluvial fan, water readily infiltrates the unconsolidated sediments; there was zero flow at site 22 in July (table 2), and a loss of more than $2 \mathrm{ft}^{3} / \mathrm{s}$ in November. Flow between sites 22 and 23 is affected by a spring which flows into Smoke Creek about 0.25 mi upstream from site 23; this spring is probably fed by infiltration from Smoke Creek further upstream. There was a gain of about $0.5 \mathrm{ft}^{3} / \mathrm{s}$ from site 22 to site 23 in July and a loss of about $0.7 \mathrm{ft}^{3} / \mathrm{s}$ in November. Total loss for the lower stream reach between sites 21 and 23 was about $1.2 \mathrm{ft}^{3} / \mathrm{s}$ in July and $3.1 \mathrm{ft}^{3} / \mathrm{s}$ in November. The measurements show that infiltration averaging about $2 \mathrm{ft}^{3} / \mathrm{s}$ recharged the aquifer between sites 21 and 23 .

\section{Squaw, Buffalo, and Dry Creeks}

Miscellaneous measurements on Squaw Creek at sites 1-3 (table 2 and fig. 8) show that 0.6 and $1.2 \mathrm{ft}^{3} / \mathrm{s}$ was gained between sites 1 and 2 in summer and winter months, respectively; as much as $2.3 \mathrm{ft}^{3} / \mathrm{s}$ was lost to infiltration and recharged the underlying aquifer between sites 2 and 3. Ground-water levels in adjacent volcanic rocks are probably above the altitude of the streambed between sites 5 and 6 and are estimated to be at about $4,200 \mathrm{ft}$. Because more than 2 in. of precipitation fell in the basin (fig. 8) before the January measurement, base-flow conditions cannot be assumed and evapotranspiration cannot be estimated from winter and summer measurements.

On Buffalo Creek, the flow measured in July 1988 was very low, and measurements indicated that the stream was losing flow between sites 4 and 6 (table 2 and fig. 8). The water could have been lost to infiltration or, given the low flow rate, lost to evaporation. In January 1989 , about $0.7 \mathrm{ft}^{3} / \mathrm{s}$ was gained between sites 4 and 6 on Buffalo Creek $\left(0.5 \mathrm{ft}^{3} / \mathrm{s}\right.$ between sites 4 and 5 and $0.2 \mathrm{ft}^{3} / \mathrm{s}$ between sites 5 and 6). Because of precipitation in November and late December 1988, base-flow conditions cannot be assumed and ground-water levels in adjacent volcanic rocks cannot be compared with the altitude of the streambed in that area. No flow was observed near the Espil Ranch during the measurements; therefore, as much as $3.0 \mathrm{ft}^{3} / \mathrm{s}$ was lost to infiltration near the top of the alluvial fan and recharged the aquifer.

Crest-stage gages, which record only peak flows, were installed on Buffalo Creek (December 16, 1988) and on Squaw Creek (October 18, 1988), and one was reactivated on Dry Creek on September 15, 1988. The drainage areas above the gages on Buffalo, Squaw, and Dry Creeks are 206, 71, and $3.5 \mathrm{mi}^{2}$, respectively.

Two peaks were recorded at Buffalo Creek: about $810 \mathrm{ft}^{3} / \mathrm{s}$ from snowmelt on February 24, 1989, and about $850 \mathrm{ft}^{3} / \mathrm{s}$ from precipitation July 14-19, 1990 (table 3). Streamflow measured at the crest-stage gage on Buffalo Creek ranged from about 0.75 to $7.9 \mathrm{ft}^{3} / \mathrm{s}$. A single peak estimated at $1,450 \mathrm{ft}^{3} / \mathrm{s}$ was recorded at Squaw Creek from snowmelt on February 24, 1989. Discharge at Squaw Creek ranged from about 0.50 to $2.5 \mathrm{ft}^{3} / \mathrm{s}$. Only small peaks ranging from 0.024 to $3.26 \mathrm{ft}^{3} / \mathrm{s}$ were recorded at Dry Creek from precipitation and snowmelt. 


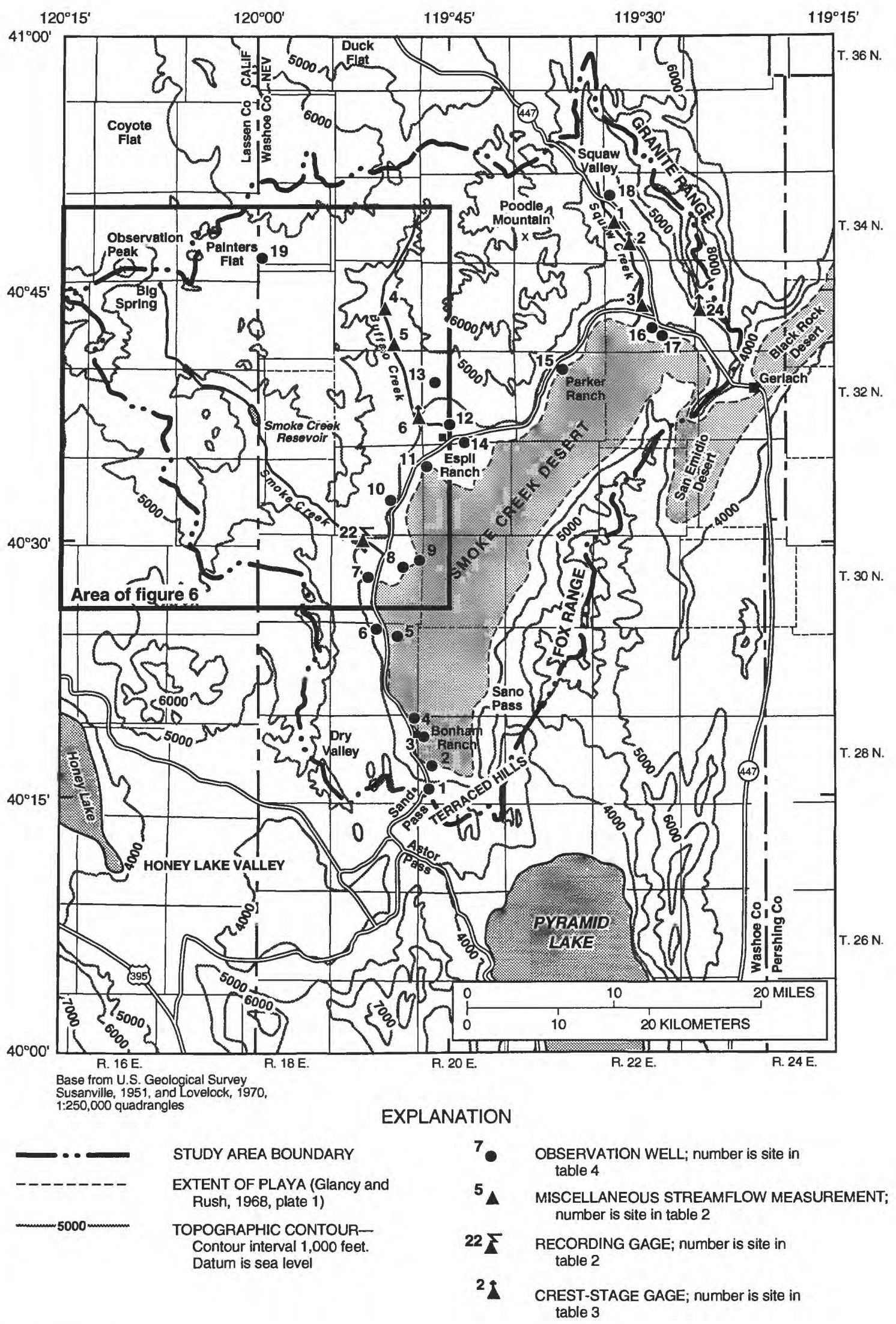

FIGURE 8.--Surface-water and ground-water data-collection networks developed for the study area. 
The snowmelt on February 24, 1989, produced similar runoff peaks at Smoke and Buffalo Creeks ( 860 and $810 \mathrm{ft}^{3} / \mathrm{s}$, respectively). Smoke and Buffalo Creeks drain areas of similar size (224 and $206 \mathrm{mi}^{2}$, respectively) and similar altitudes. A larger peak of $1,450 \mathrm{ft}^{3} / \mathrm{s}$ was estimated for Squaw Creek on this day even though it has a much smaller drainage area--only $71 \mathrm{mi}^{2}$. This large peak could have resulted from runoff from the Granite Range, which bounds the drainage on the east. The higher altitudes of the Granite Range probably receive more snow, and the granitic rocks of the Range are less permeable to infiltration than the volcanic rocks of the Smoke and Buffalo Creek drainages.

Further inferences on the characteristics of drainage-basin response to precipitation using the data from crest-stage gages are not warranted because of the short period of record. Continued data collection for 5 to $10 \mathrm{yr}$ would provide a data base to compare characteristics of these drainages.

TABLE 3. Data from crest-stage gages in Smoke Creek Desert basin, water years 1989-90

[Abbreviations: $\mathrm{ft}^{3} / \mathrm{sec}$, cubic foot per second; $\mathrm{mi}^{2}$, square mile]

\begin{tabular}{|c|c|c|c|c|c|c|c|}
\hline $\begin{array}{c}\text { Site } \\
\text { number } \\
\text { (fig. 8; } \\
\text { table 3) }\end{array}$ & Location & $\begin{array}{c}\text { Drainage } \\
\text { area } \\
\left(\mathbf{m i}^{\mathbf{2}}\right)\end{array}$ & $\begin{array}{l}\text { Gaging } \\
\text { station }\end{array}$ & $\begin{array}{c}\text { Date } \\
\text { measured }\end{array}$ & $\begin{array}{c}\text { Discharge } \\
\left(\mathrm{ft}^{3} / \mathrm{sec}\right)\end{array}$ & $\begin{array}{c}\text { Estimated } \\
\text { peak } \\
\left(\mathrm{ft}^{3} / \mathrm{sec}\right)\end{array}$ & Remarks \\
\hline \multirow[t]{9}{*}{6} & \multirow[t]{9}{*}{ Buffalo Creek } & \multirow[t]{9}{*}{206} & \multirow[t]{9}{*}{10303798} & $12-16-88$ & 0.98 & - & Station gage installed \\
\hline & & & & $1-18-89$ & 3.00 & -- & No peak \\
\hline & & & & $2-24-89$ & -- & 810 & Snowmelt (Feb. 24, 1989) \\
\hline & & & & $3-17-89$ & 7.90 & - & No peak \\
\hline & & & & $12-19-89$ & $\mathrm{a}_{3.0}$ & -- & No peak \\
\hline & & & & $1-22-90$ & ${ }^{a} 2.0$ & -- & No peak \\
\hline & & & & $3-05-90$ & 6.51 & - & No peak \\
\hline & & & & $4-11-90$ & a. 75 & -- & No peak \\
\hline & & & & $7-19-90$ & -- & 850 & Precipitation (July 14-19, 1990) \\
\hline \multirow[t]{11}{*}{2} & \multirow[t]{11}{*}{ Squaw Creek } & \multirow[t]{11}{*}{71} & \multirow[t]{11}{*}{10353795} & $10-18-88$ & 1.56 & -- & Station gage installed \\
\hline & & & & $1-17-89$ & 2.29 & -- & No peak \\
\hline & & & & $5-15-89$ & - & 1,450 & Snowmelt (peak Feb. 24-25, 1989) \\
\hline & & & & $9-07-89$ & 1.07 & - & No peak \\
\hline & & & & $12-19-89$ & ${ }^{\mathrm{a}} 1.5-2.0$ & -- & No peak \\
\hline & & & & $1-22-90$ & ${ }^{\mathrm{a}} 2.5$ & -- & No peak \\
\hline & & & & $3-05-90$ & 1.98 & -- & No peak \\
\hline & & & & $4-11-90$ & $\mathrm{a}_{1.0}$ & -- & No peak \\
\hline & & & & $6-14-90$ & 1.18 & - & No peak, moss on control \\
\hline & & & & $8-15-90$ & a $.5-.6$ & -- & No peak \\
\hline & & & & $10-18-90$ & ${ }^{\mathrm{a}} 1.5-2$ & -- & No peak \\
\hline \multirow[t]{10}{*}{24} & \multirow[t]{10}{*}{ Dry Creek } & \multirow[t]{10}{*}{3.5} & \multirow[t]{10}{*}{10353730} & $9-15-88$ & -- & -- & No flow since last visit \\
\hline & & & & $10-18-88$ & -- & -- & No flow since last visit \\
\hline & & & & $1-18-89$ & a .1 & - & No peak \\
\hline & & & & $3-17-89$ & -- & 2.00 & Snowmelt (Feb. 24, 1989) \\
\hline & & & & $5-15-89$ & -- & 3.02 & Precipitation (May 9-10, 1989) \\
\hline & & & & $6-21-89$ & -- & 3.26 & Precipitation (early to middle June) \\
\hline & & & & $7-12-89$ & -- & - & No flow since last visit \\
\hline & & & & $9-07-89$ & -- & .50 & Precipitation (Sept. 6, 1989) \\
\hline & & & & $12-19-89$ & - & .02 & Precipitation (around Nov. 25,1989 ) \\
\hline & & & & $10-18-90$ & -- & - & No flow since last visit \\
\hline
\end{tabular}

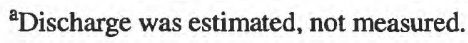




\section{GROUND-WATER FLOW}

\section{Ground-Water Levels and Fluctuations}

For waters of like density, ground water moves by gravity from areas of higher altitude to areas of lower altitude. Figure 9 shows the average water-level altitudes measured in the Smoke Creek Desert and adjacent basins. The arrows indicate the potential direction of ground-water flow. Interbasin flow is discussed in the next section. Most of the water levels are measured in wells completed in unconsolidated sediments. Only two of the wells, near Sand Pass (sites 21 and 23), tap volcanic rocks. Thus, much less is known about water levels and movement of water through the volcanic rocks than through the unconsolidated sediments.

Within the Smoke Creek basin, the altitudes of the water levels indicate that ground water probably flows from the highlands in the north and west toward the playa. Also, a gradient in the water table beneath the alluvial fans drives the flow of ground water on the west side of the basin toward the playa. Although no wells exist to measure on the east side of the basin, there is probably a similar gradient beneath the alluvial fans toward the playa.

Many of the flowing wells near the edge of the playa have hydraulic heads ranging from just above land surface to about $12 \mathrm{ft}$ above land surface. The wells were installed near the turn of the century, and details of their construction are not available. They were probably installed by cable-tool drilling; driving the casing until the desired flow rate was obtained. This method results in an open-ended casing, and finegrained sediments near the edge of the playa form a natural seal along the upper part of the casing. The depth of the flowing wells range from about $30 \mathrm{ft}$ to more than $200 \mathrm{ft}$. Hydraulic head increases with well depth in wells just east of Smoke Creek by about $10 \mathrm{ft}$ of head in $55 \mathrm{ft}$ of depth. The increase in head indicates upward ground-water flow near the margin of the playa. The numerous springs and flowing wells surrounding the playa provide additional evidence that an upward gradient probably prevails near the margin of the playa around the entire basin.

Depth to water ranges from $5-7 \mathrm{ft}$ below land surface beneath the playa (Glancy and Rush, 1968, p. 31) to more than $200 \mathrm{ft}$ below land surface beneath the heads of the alluvial fans. Depth to water in volcanic rocks on the west side of the basin is not well known. Numerous perennial springs in the volcanic rocks could result from perched water trapped above welded zones in the volcanic rocks.

Data collected during a ground-water inventory are shown on plate 2 and listed in table 4 . From these wells, a network of 19 wells was established where depth to water, pressure head, flow rate, water temperature, and specific conductance were measured periodically (fig. 8). None of the flowing wells in the network have cement surface seals, and water may leak to the well annulus; therefore, pressure head measured when the wells are closed off and the measured flow rate might be lower than the actual value.

Hydrographs of water levels show fluctuations of about $1 \mathrm{ft}$ during the study period at most wells (fig. 10). One exception was well 12. Well 12 is one of two irrigation wells at the Espil Ranch, the only site in the basin with significant ground-water pumpage. The water level in well 12 declined about $20 \mathrm{ft}$ from 1988 to 1990; however, the well was pumped during the irrigation season for the first time in 1990. Slight declines in water levels were also seen at wells $1,9,11$, and 16. Precipitation below normal since 1988 probably caused the declines measured at all wells except well 12 , where the water level is probably adjusting to the increased pumping during 1990 . Well 8 showed about a 1-ft rise in pressure head from 1989 to 1990 , even though precipitation has been below normal for 3 years. This rise in water level is difficult to explain. Flow rates measured at network wells did not change significantly during the study period (table 4).

\section{Interbasin Flow}

In the Fox and Granite Ranges, granitic and metamorphic bedrock probably blocks any flow of ground water across the eastern surface-water divide of the basin. Around most of the basin boundary, permeable volcanic rocks combined with relatively low, subtle surface-water divides might allow ground water to flow in either direction across the surface-water divide (fig. 9). The precise location of ground-water divides between adjacent basins cannot be determined without drilling additional wells around the perimeter of the basin. 


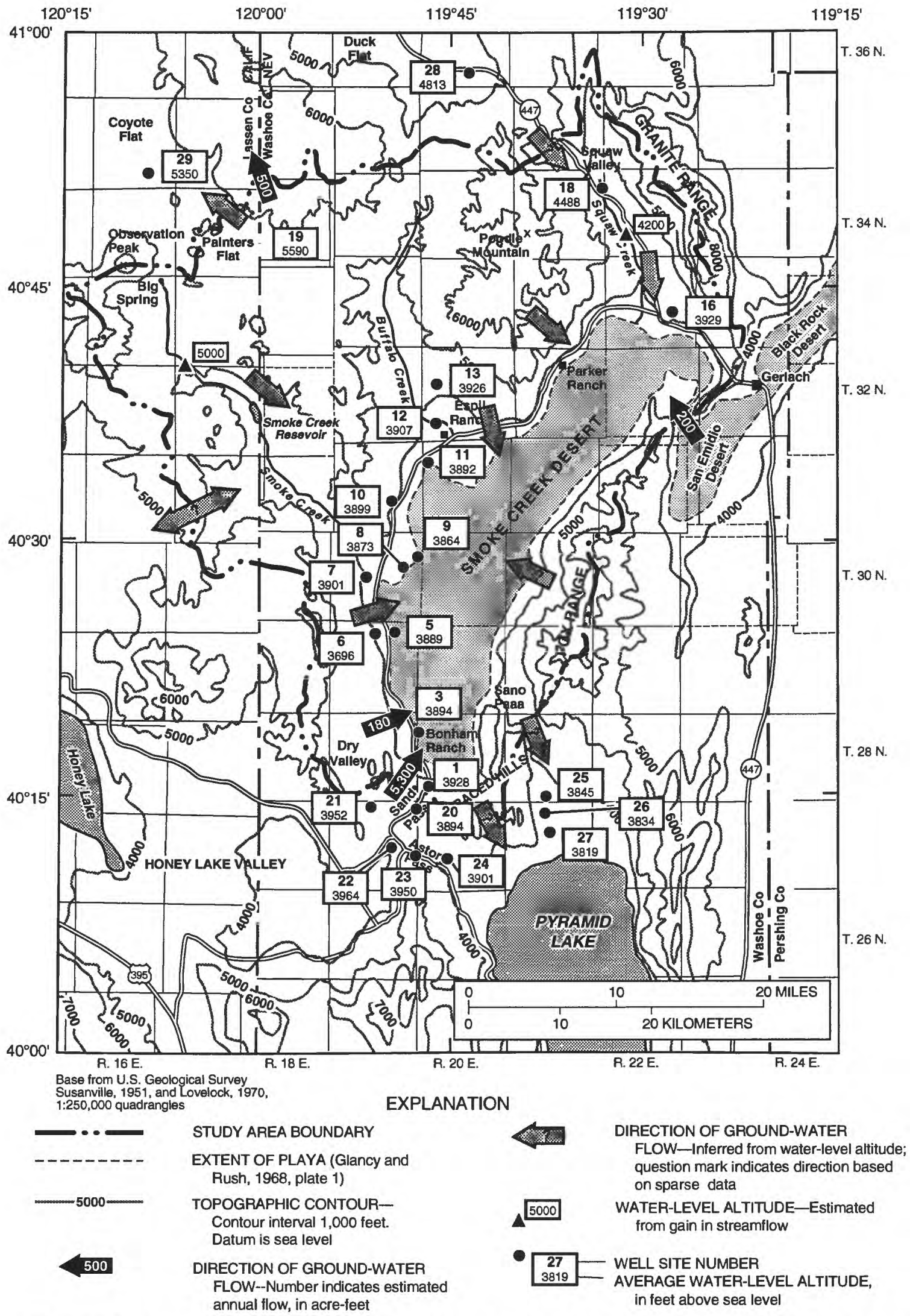

FIGURE 9.--Average water-level altitudes for selected wells in Smoke Creek Desert basin and adjacent basins during 1988 and 1989. Annual flow estimated from Glancy and Rush (1968), except for 5,300 acre-feet from Honey Lake basin estimated by Handman and others (1990); 5,300 acre-feet per year includes the 180 acre-feet per year shown in the figure coming from Dry Valley. 


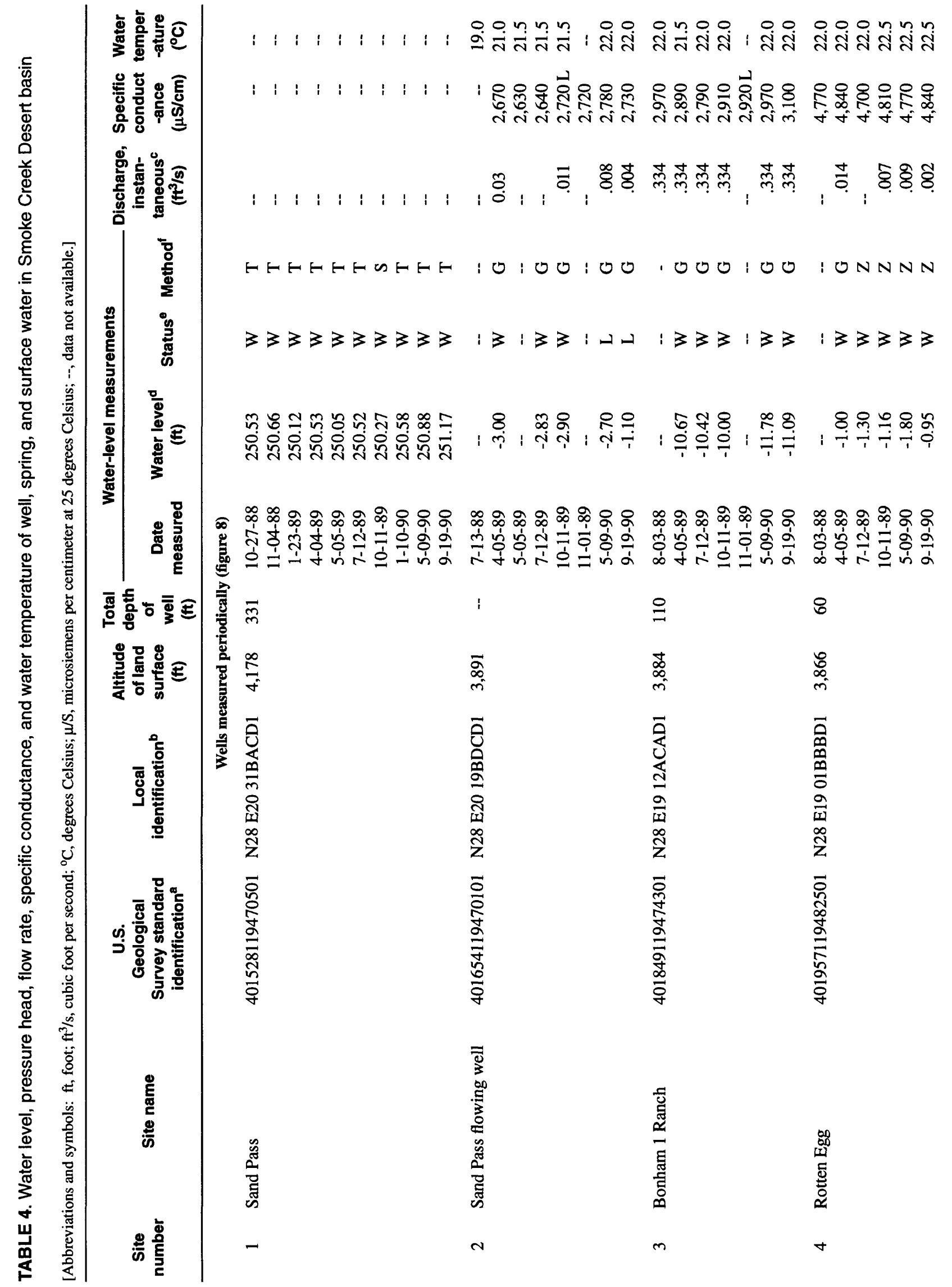




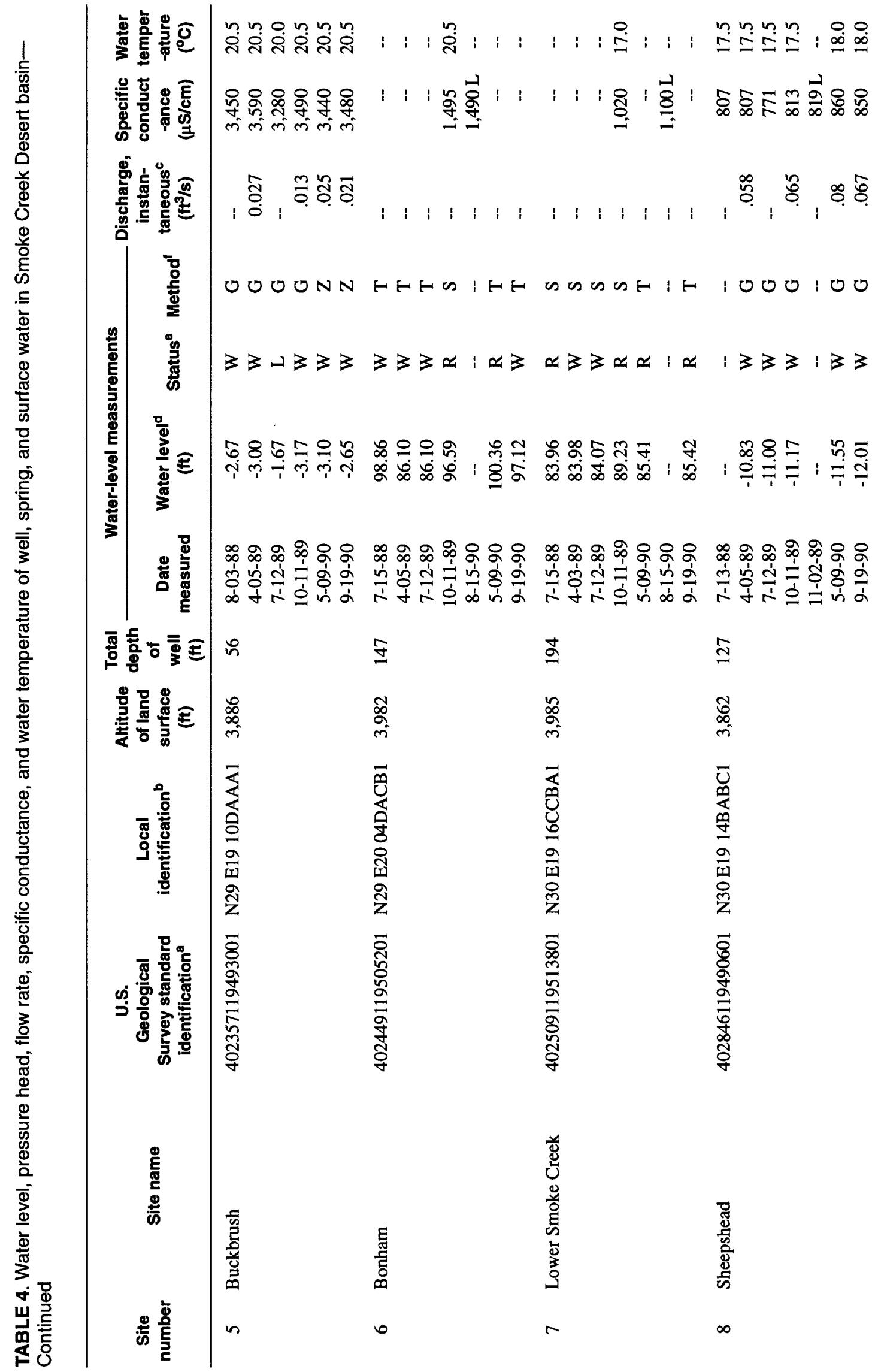




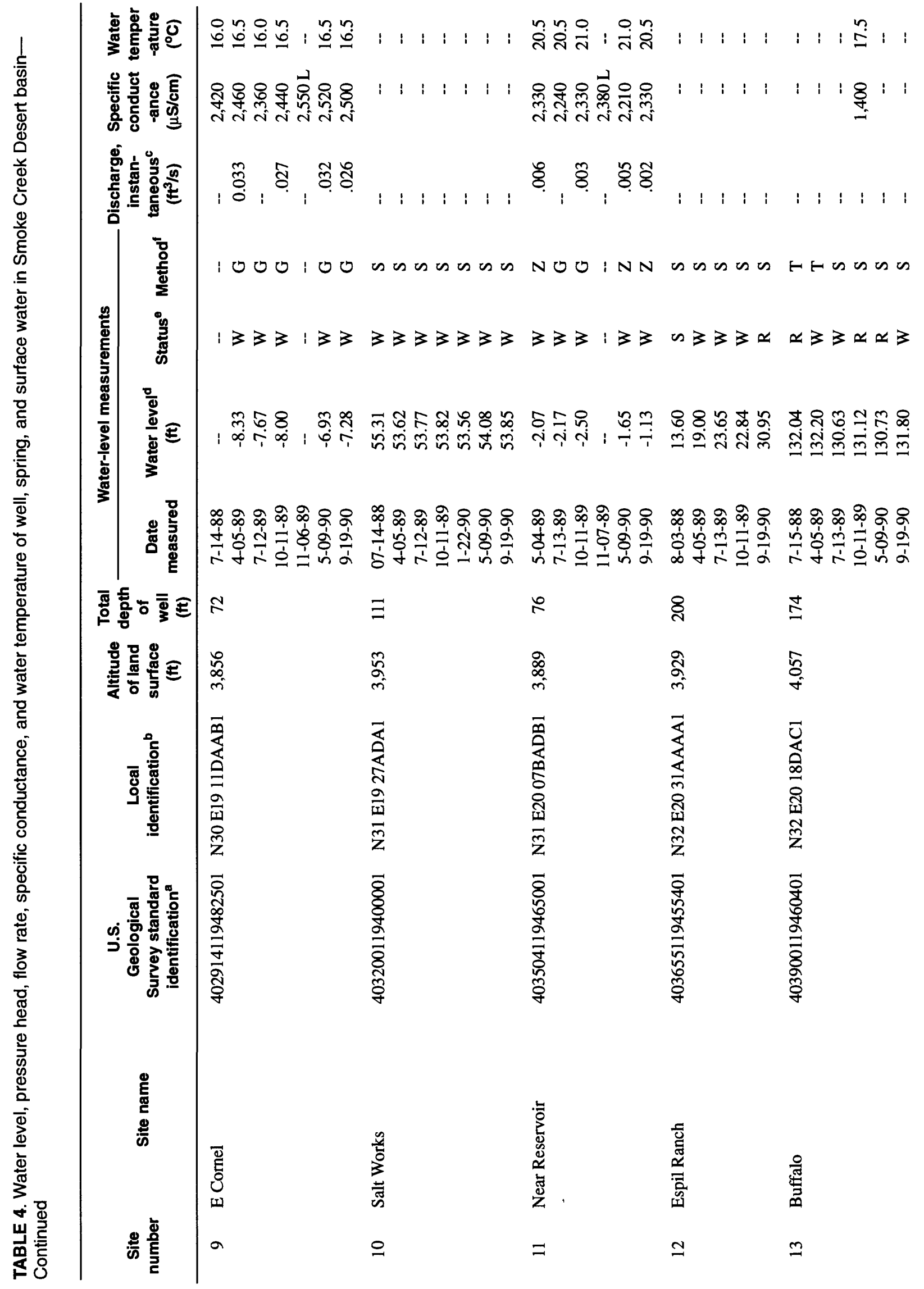




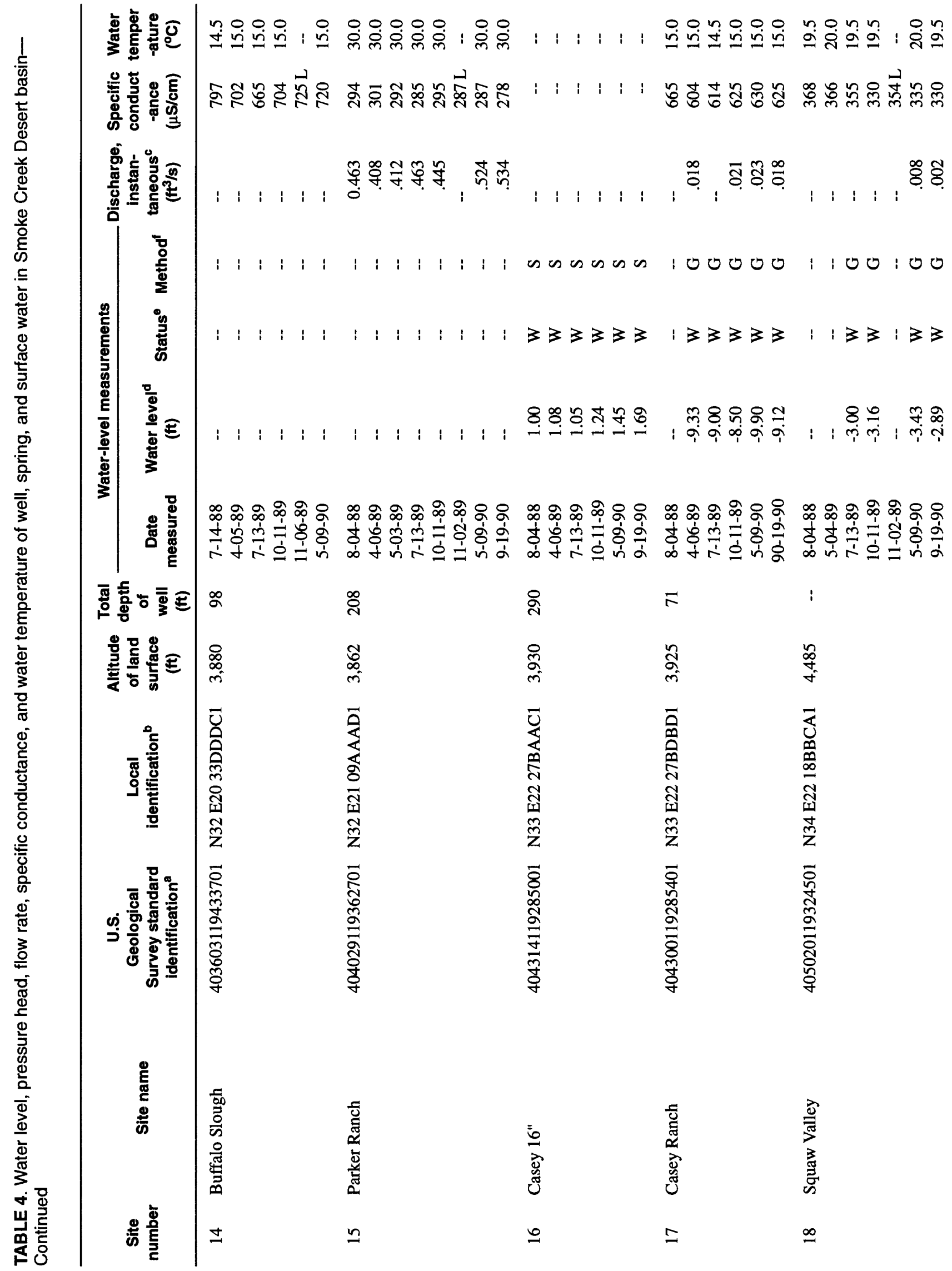




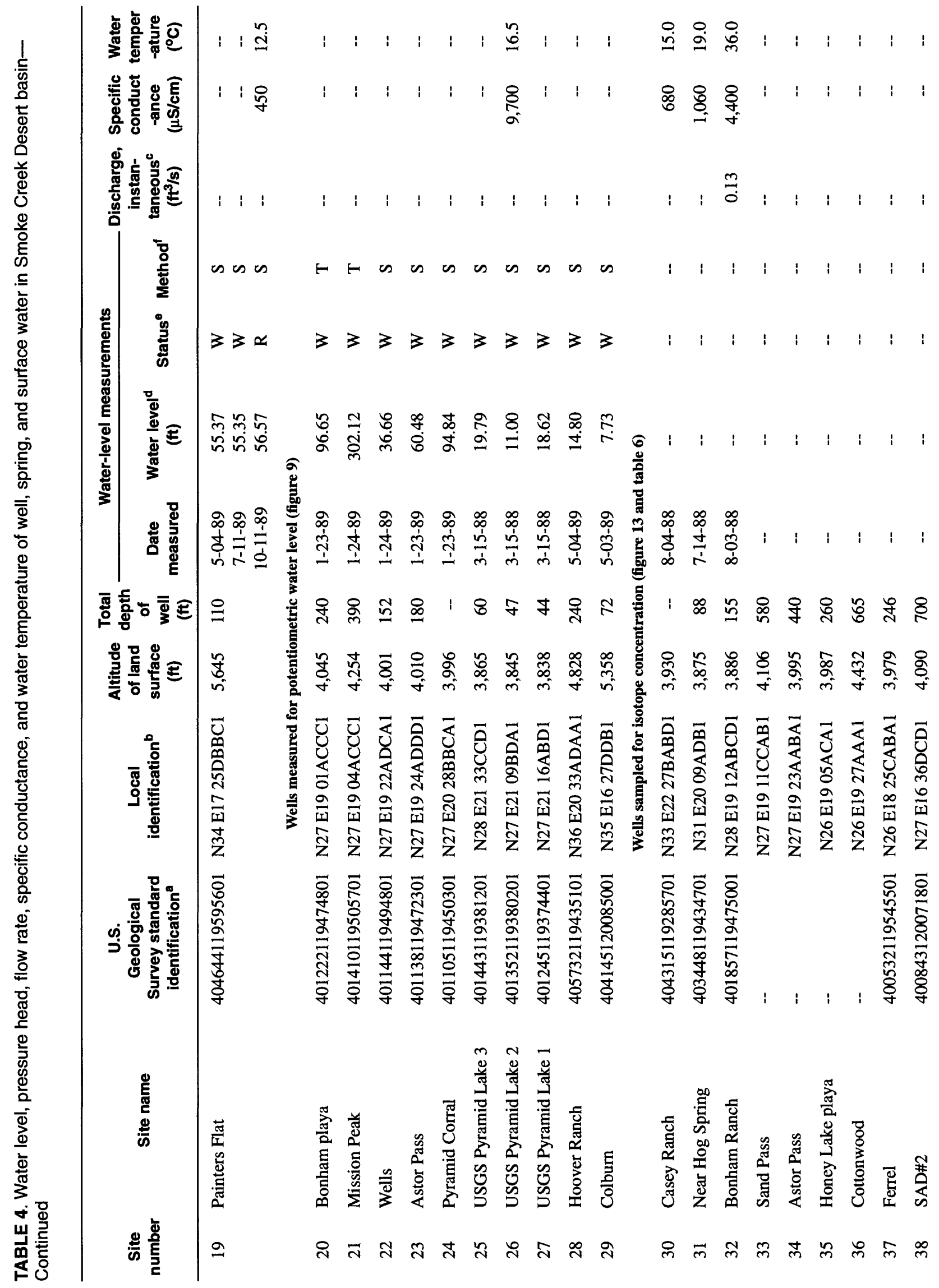




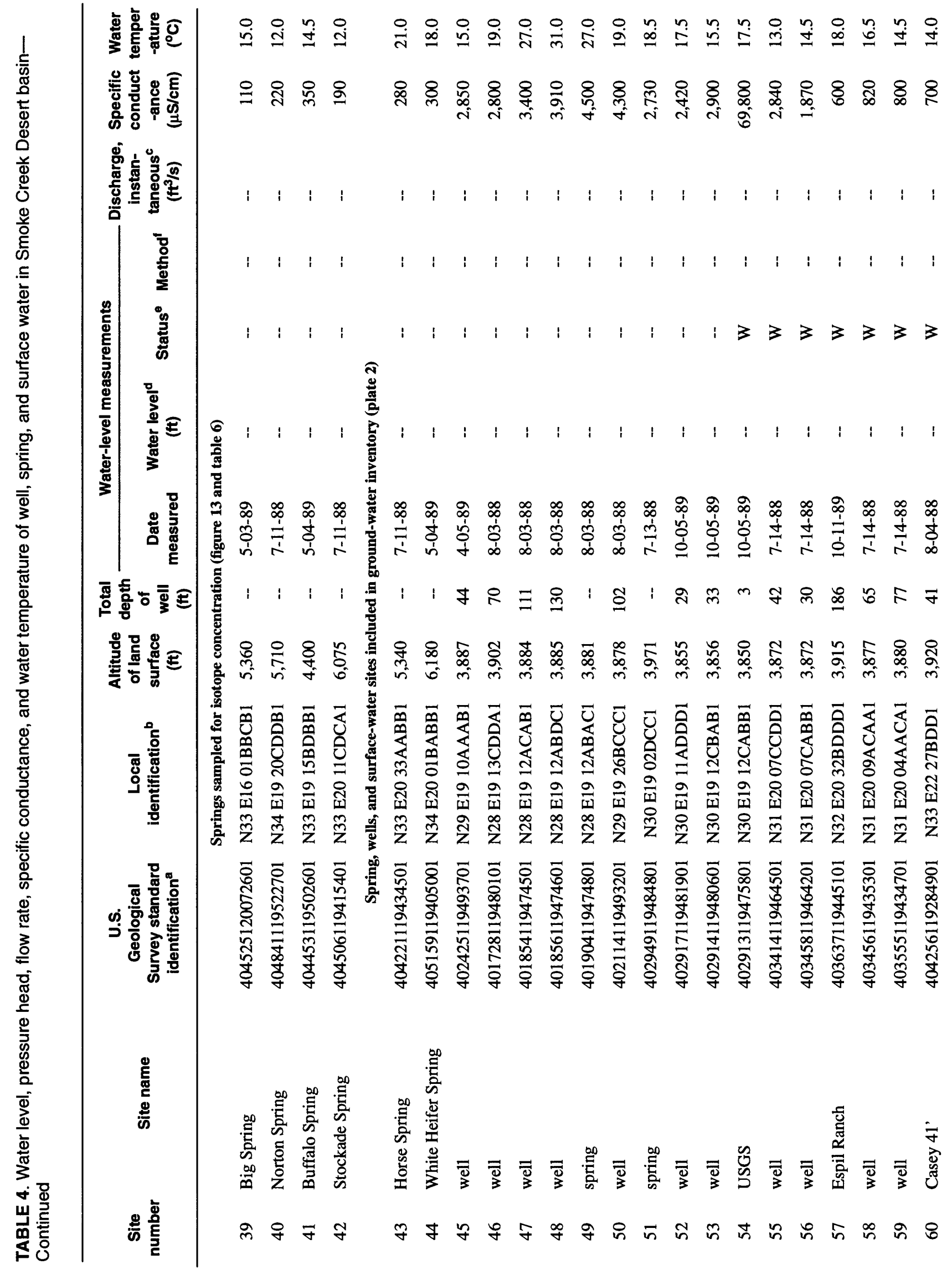




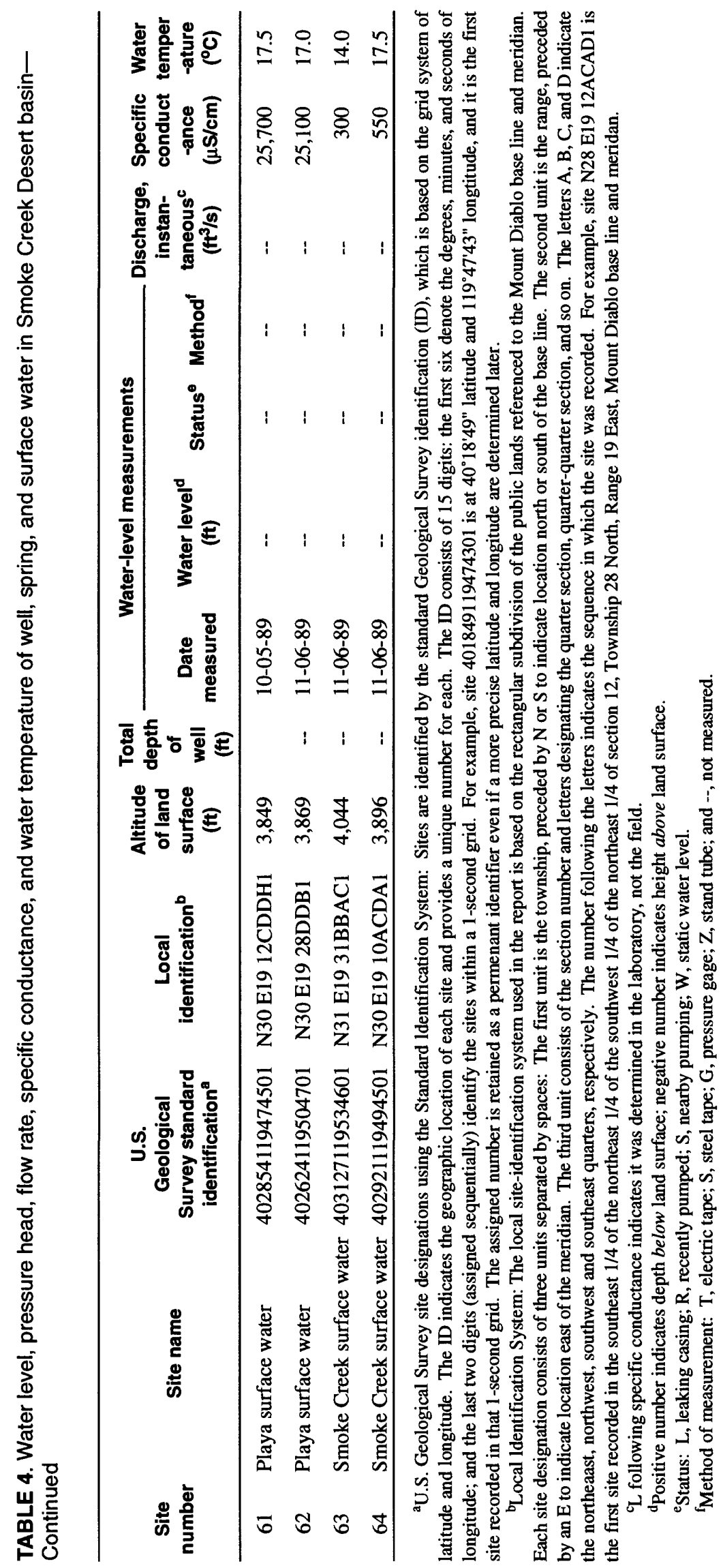




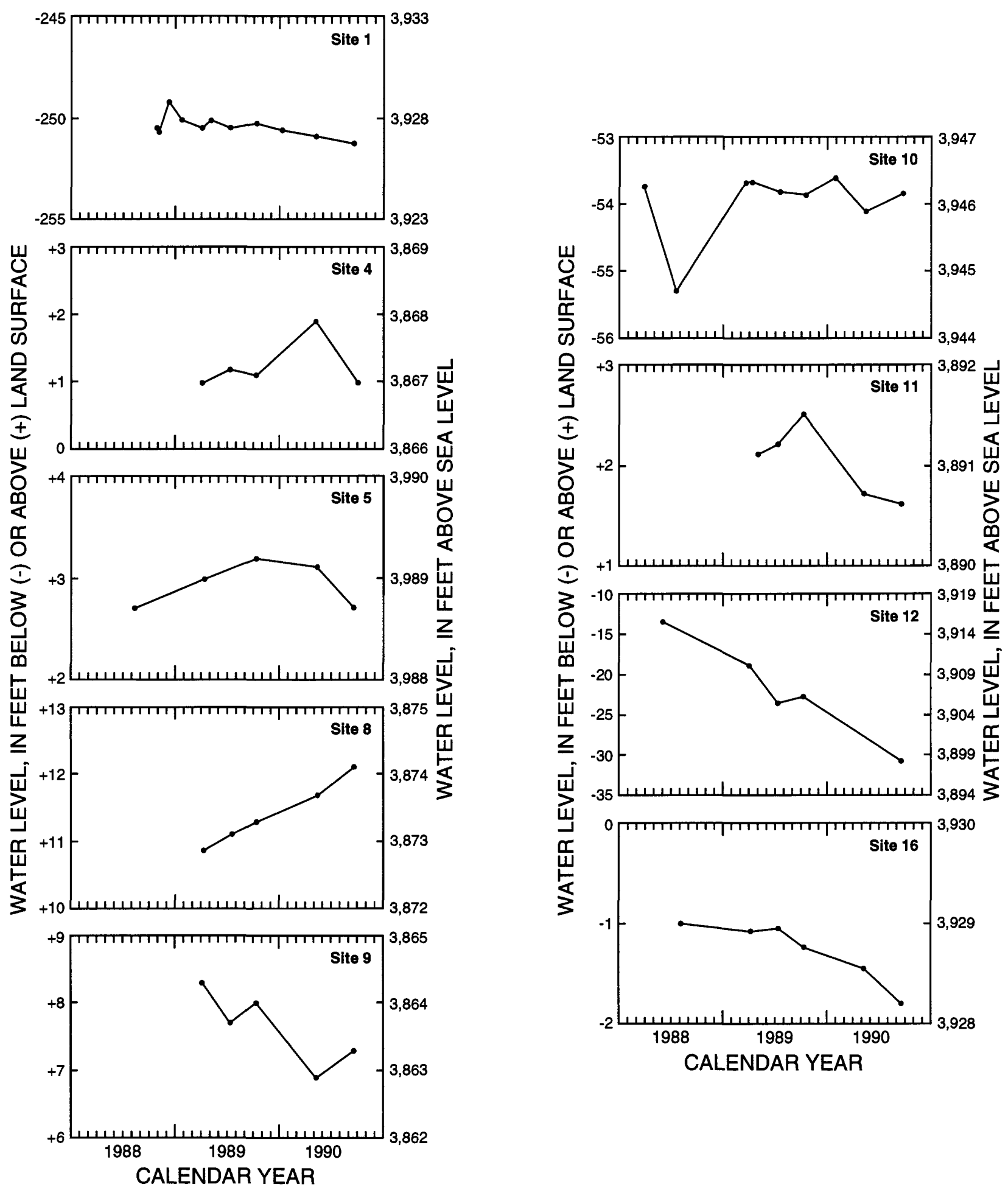

FIGURE 10.--Fluctuations of water levels in selected wells in Smoke Creek Desert basin, 1988-90.

(Site locations are shown in figure 8.) 
Previous workers have estimated underflow between some adjacent basins (fig. 9). From the east, Glancy and Rush (1968, p. 28) estimated ground-water flow of about 200 acre- $\mathrm{ft} / \mathrm{yr}$ from the San Emidio Desert to the Smoke Creek Desert basin through the gap between the Fox and Granite Ranges. Water levels indicate a continuous gradient from the Honey Lake basin into the southwest corner of Smoke Creek Desert. Handman and others (1990, p.104) estimated that ground-water flow may be about 5,300 acre-ft/yr from Honey Lake to Smoke Creek basin. Included in this estimate is about 180 acre-ft/yr of ground-water flow from Dry Valley to the Smoke Creek basin proposed by Glancy and Rush (1968, p. 28). The additional inflow of about 5,120 acre-ft/yr estimated by Handman and others (1990) provides a more precise balance of the water budget estimated by Glancy and Rush (1968, p. 41) and suggests that annual recharge to the basin could be about 19,000 acre-ft/yr. Water levels indicate a potential for flow toward the northwest from Painters Flat to Coyote Flat, and Glancy and Rush (1968, p. 28) estimate $500 \mathrm{acre}-\mathrm{ft} / \mathrm{yr}$ of underflow north of Painters Flat to the northwest. Water levels on the north side of the basin indicate a potential for flow from the north near Duck Flat to Squaw Valley. Water levels in the north end of Pyramid Lake basin show a potential for flow from the Smoke Creek basin toward Pyramid Lake.

\section{ESTIMATED COMPONENTS OF THE BASIN WATER BUDGET}

Dry conditions during the study period allowed accurate measurements of streamflow to determine volumes of gain and loss along certain reaches of the stream. Identification of areas that gain or lose streamflow and the measured rates of flow provide important data on how ground water and surface water interact in Smoke Creek Desert basin. These new data allow estimation of some components of the basin water budget. Because of the dry conditions, however, the estimates probably provide lower limits, rather than average values, for the components.

\section{Ground-Water Discharge to Streamflow}

Streamflow measurements in the upper reach of Smoke Creek indicated a $2.0 \mathrm{ft}^{3} / \mathrm{s}$, or about 1,450 acre$\mathrm{ft} / \mathrm{yr}$, discharge of ground water to streamflow. Gains in streamflow at Buffalo Creek and between the upper two sites at Squaw Creek totaled $1.9 \mathrm{ft}^{3} / \mathrm{s}$, or about 1,370 acre- $\mathrm{ft} / \mathrm{yr}$. The rounded total for measured ground-water discharge to streamflow is 2,800 acre$\mathrm{ft} / \mathrm{yr}$ in the Smoke Creek Desert basin. In all three drainage basins, streamflow was gained in or near outcrop areas of volcanic rock. Thus, the upland volcanic rock aquifer is probably a source for base streamflow in these drainage basins. These streams ultimately recharge the unconsolidated aquifer on the valley floor. Because water levels did not decline appreciably during the study period, the measured ground-water discharge to streamflow may represent an accurate estimate of the base-flow contribution from the volcanic rock aquifer.

\section{Ground-Water Recharge from Streamflow}

Loss of streamflow measured at Smoke, Buffalo, and Squaw Creeks is direct evidence of recharge to unconsolidated sediments. The total streamflow loss measured at Smoke Creek was $4.9 \mathrm{ft}^{3} / \mathrm{s}\left(1.2 \mathrm{ft}^{3} / \mathrm{s}\right.$ in the upper canyon reach; $1.7 \mathrm{ft}^{3} / \mathrm{s}$ in the meadow reach; and an average of $2.0 \mathrm{ft}^{3} / \mathrm{s}$ in the lower reach) or about $3,500 \mathrm{acre}-\mathrm{ft} / \mathrm{yr}$. Streamflow loss at Squaw and Buffalo Creeks totaled $5.3 \mathrm{ft}^{3} / \mathrm{s}$ or about 3,800 acre- $\mathrm{ft} / \mathrm{yr}$. Thus, these field measurements indicate that a total of about 7,300 acre-ft/yr recharged unconsolidated sediments at Smoke, Buffalo, and Squaw Creeks.

Glancy and Rush (1968, p. 24) estimate that 90 percent of the runoff for the entire Smoke Creek Desert basin is derived from the drainages of Smoke, Buffalo, and Squaw Creeks. If these same areas provide 90 percent of the recharge to the basin-fill deposits, 11,700 acre-ft/yr of the 13,000-acre-ft/yr recharge estimated by Glancy and Rush (1968, p. 29) for the entire basin comes from these drainages. If the 7,300 acre- $\mathrm{ft} / \mathrm{yr}$ measured in this study represents a minimum value of ground-water recharge from streamflow during drought years, $11,700 \mathrm{acre}-\mathrm{ft} / \mathrm{yr}$ appears to remain a reasonable average annual value. Measurements along stream channels during years of normal runoff would provide a more reliable estimate of this component of recharge. 


\section{Evapotranspiration of Streamflow}

\section{Differences between November and July} stream-flow measurements on Smoke Creek indicate that a total of $2.1 \mathrm{ft}^{3} / \mathrm{s}$, or about $1,500 \mathrm{acre}-\mathrm{ft} / \mathrm{yr}$, was lost to evapotranspiration along the stream channel. About 500 acre-ft/yr was lost through the meadow reach and is included in evapotranspiration estimates of Glancy and Rush (1968, p. 32). Similar losses could occur at Buffalo and Squaw Creeks, but the measurements available are inadequate to estimate the loss.

Glancy and Rush (1968, p. 32) estimate that $11,000 \mathrm{acre}-\mathrm{ft} / \mathrm{yr}$ is lost from bare soil evaporation of ground water beneath the playa. In addition, the bulk of the water from large storms is probably lost to evaporation after flow has ponded on the playa (P.A Glancy, U.S. Geological Survey, oral commun., 1992). About 560 acre-ft of runoff is estimated from the peak flow of $845 \mathrm{ft}^{3} / \mathrm{s}$ recorded at Smoke Creek on February 24,1989 . A similar peak flow of $810 \mathrm{ft}^{3} / \mathrm{s}$ was estimated at Buffalo Creek (table 4). Although the runoff at Squaw Creek had a larger peak flow $(1,450 \mathrm{ft} / \mathrm{s})$, it may not have lasted as long. If one assumes that a volume about equal to that measured at Smoke Creek was produced from peak flows at Buffalo and Squaw Creeks, a minimum of about 1,680 acre-ft of runoff probably ponded on the playa in 1989 and was lost to evaporation. In 1990, a peak flow of $850 \mathrm{ft}^{3} / \mathrm{s}$ at Buffalo Creek and $38 \mathrm{ft}^{3} / \mathrm{s}$ (Bostic and others, 1991, p. 289) at Smoke Creek from a thunderstorm produced less than 200 acre-ft of runoff. These measurements show that even in dry years, from 200 to $1,680 \mathrm{acre}-\mathrm{ft} / \mathrm{yr}$ of runoff will reach the playa and will be lost to evaporation.

\section{WATER QUALITY}

Specific conductance, water temperature, concentrations of dissolved constituents, and isotope composition of ground water in Smoke Creek Desert basin was measured (1) to provide data from which inferences on ground-water movement could be made; (2) to determine the distribution of water quality and compare it to Nevada drinking-water standards; and (3) to establish base-line values for determining the effects of future development.

\section{Specific Conductance}

Measurements of specific conductance and water temperature in the Smoke Creek Desert basin are summarized on plate 2 . The specific conductance of water is directly related to the amount of dissolved solids in the sample (Hem, 1985, p. 66) and is an approximate measure of the ground-water quality. Generally, specific-conductance values in sampled ground water range from 100 to $400 \mu \mathrm{S} / \mathrm{cm}$ in the mountain blocks to the north and west, and about $570 \mu \mathrm{S} / \mathrm{cm}$ was measured in a spring in the Fox Range Specific conductance increases to 1,000 to $1,500 \mu \mathrm{S} / \mathrm{cm}$ beneath the alluvial fans and reaches a maximum of about $5,000 \mu \mathrm{S} / \mathrm{cm}$ in water from flowing wells near the playa. Exceptions to this are wells south of Buffalo Creek (sites 14, 31, 58, and 59), south of Squaw Creek (sites 17 and 60), and east of Smoke Creek (site 8). Although they are near the playa, water from these wells has a specific conductance of less than about $1,000 \mu \mathrm{S} / \mathrm{cm}$. These wells could be tapping lobes of ground water that is more dilute because of infiltration of streamflow upgradient from the wells. Also, water from the well at the Parker Ranch (site 15) has a specific conductance comparable with values measured in the volcanic uplands although it is near the playa. The lower concentration of dissolved solids in water from this well is evidence of dilute ground water from the adjacent volcanic mountain block recharging the alluvial-fan and playa deposits.

A plot of specific conductance as a function of well depth shows two distinct groups of sites (fig. 11). Sites with a specific conductance less than $1,500 \mu \mathrm{S} / \mathrm{cm}$ show no relation between specific conductance and well depth. These sites are located on alluvial fans or near sources of streamflow infiltration. Sites with a specific conductance greater than $1,500 \mu \mathrm{S} / \mathrm{cm}$ are located near the playa and show a general trend of increasing specific conductance with well depth. However, the deepest well for which data are available is only about $150 \mathrm{ft}$ deep (site 32 ). Deeper wells are needed to determine the vertical distribution of specific conductance within the basin-fill sediments.

The specific conductance of streamflow in Smoke Creek (triangles, pl. 2) increases from $110 \mu \mathrm{S} / \mathrm{cm}$ at Big Spring to $300 \mu \mathrm{S} / \mathrm{cm}$ in the lower canyon reach (see fig. 6) and to $550 \mu \mathrm{S} / \mathrm{cm}$ where it approaches the playa. Evaporation and dissolution of salts on the playa surface greatly increase the specific 
conductance of surface water ponded on the playa. Standing water sampled on the edge of the playa had a specific conductance of about $25,000 \mu \mathrm{S} / \mathrm{cm}$.

Only one measurement of specific conductance might be representative of ground water beneath the playa. This was from a shallow well installed to a depth of $3 \mathrm{ft}$ near standing water at the lowest point of the playa (site 54). Specific conductance was about $70,000 \mu \mathrm{S} / \mathrm{cm}$. More wells are needed on the playa to evaluate whether most ground water beneath it has such high specific conductance.

High specific conductance of ground water, hence high concentration of dissolved solids, can affect how the water moves by producing density-driven flow. Water with a specific conductance of $70,000 \mu \mathrm{S} / \mathrm{cm}$ (or about $50,000 \mathrm{mg} / \mathrm{L}$ dissolved solids) has a density significantly higher $\left(1.05 \mathrm{~g} / \mathrm{cm}^{3}\right.$ at $17.5^{\circ} \mathrm{C}$ measured in the field) than that of dilute ground water. Studies have shown that ground water flows downward beneath playas of closed desert basins as the concentration of dissolved solids and the density of the ground water increases (Duffy and Al-Hassan, 1988; Wood and others, 1989; and Sanford, 1989). Duffy and AlHassan (1988, p. 1687) showed that water with the density of sea water--about $1.03 \mathrm{~g} / \mathrm{cm}^{3}$--can produce such a downward or density-driven flow. The downward flow beneath the playa can circulate ground water either toward the margin of the playa or downward into a regional flow system and out of a closed basin even when a ground-water divide exists (Sanford, 1989, and Wood and others, 1989). If permeable volcanic rocks underlie the Smoke Creek playa, the high density of ground water under the playa could drive flow down and outward toward other basins. Observation wells need to be drilled on the playa and around the perimeter to map the distribution of specific conductance and determine how ground water moves beneath the playa.

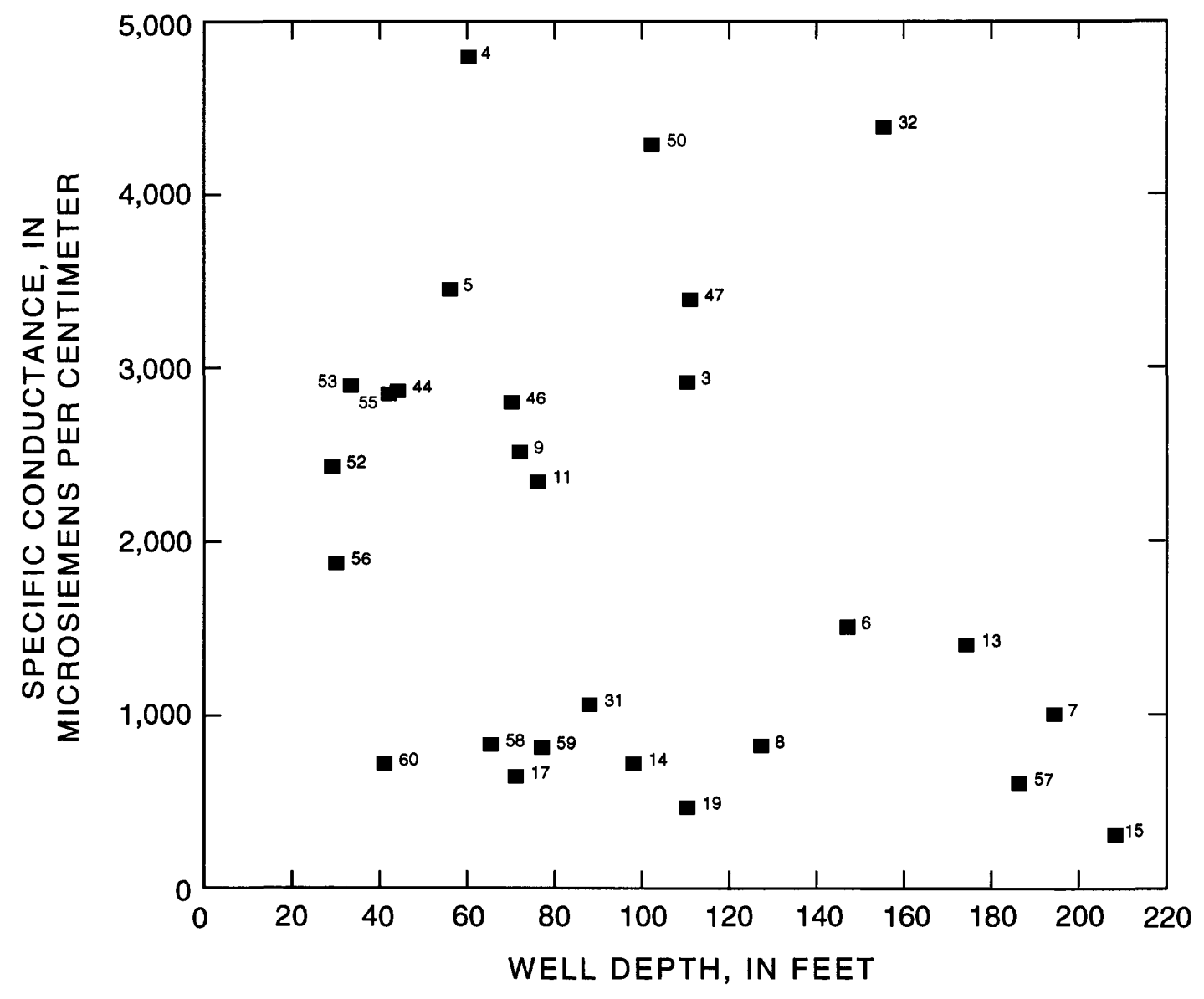

FIGURE 11.-- Relation of specific conductance to well depth in the Smoke Creek Desert basin. (Number indicates site in table 4.) 


\section{Ground-Water Temperatures}

Ground-water temperatures measured in the Smoke Creek Desert basin range from about $6^{\circ} \mathrm{C}$ to $36^{\circ} \mathrm{C}$; the lower temperatures are in the mountain blocks, and the warmest temperatures are in the deeper flowing wells at Bonham Ranch and Parker Ranch (wells 3 and 15, fig. 8). Well depth and ground-water temperature in the basin do not appear to be related. Temperatures greater than $25^{\circ} \mathrm{C}$ are believed to result from geothermal heating (Welch and Preissler, 1990, p. 12).

\section{Dissolved Constituents and Comparison with Drinking-Water Standards}

Ground-water samples from 12 sites were analyzed for dissolved-ion concentrations to compare with Nevada drinking-water standards (fig. 12, table 5). Partial analysis of a sample from site 33 was provided by Nork and Associates (written commun., February 1991). When samples were collected for the study, field determinations of $\mathrm{pH}$, specific conductance, and alkalinity were made.

Water from only two sites, 39 and 18 , did not exceed Nevada drinking-water standards for some constituents. These sites are in the upland parts of the basin and represent water that has been recently recharged. Water from sites $15,43,14,8$, and 9 exceeded the preferred standard for $\mathrm{pH}$ (table 5). Water samples from sites $7,6,9,11,2,33$, and 3 exceeded the preferred standard (table 5, footnote d) for dissolved solids, and water samples from sites $9,11,2,33$, and 3 exceeded the enforceable standard for dissolved solids. The enforceable standard for chloride was exceeded in water from sites $9,11,2$, and 3 , and the preferred standard for sulfate was exceeded at sites 2 and 3 . Water from site 11 exceeded the enforceable standard for manganese. Sites where water samples exceeded drinking-water standards were generally near the playa.

Water in upland areas of the basin near the location of recharge has a sodium and calcium bicarbonate composition and low dissolved-solids concentration (sites 39, 15, 43, and 18, fig. 12; table 5). Water of this type was sampled (1) at Big Spring, which is the source spring for Smoke Creek; (2) in Smoke Creek just before the streamflow enters the valley floor; (3) at a flowing well in Squaw Valley; and (4) at a flowing well near Parker Ranch, where the ground water is probably derived from the adjacent volcanic uplands. Ground water sampled beneath alluvial fans and on the distal edge of alluvial fans surrounding the playa (sites $14,8,7$, and 6) had a sodium bicarbonate composition and a greater dissolved-solids concentration than recharge water. Ground water sampled from flowing wells near the edge of the playa (sites 9,11,2, and 3) had a sodium chloride composition and an even greater dissolved-solids concentration.

Water types very similar to those sampled in Smoke Creek Desert were noted in Smith Creek Valley in central Nevada by Thomas and others (1989). In that valley, dissolution of rhyolitic tuffs in bedrock surrounding the valley floor and of unconsolidated tuffs in the basin-fill deposits is thought to create the original sodium and calcium bicarbonate character of the water. As water approaches the discharge area of the flow system, calcium is removed from the ground water by cation exchange of sodium on clays. Closer to the playa, dissolution of salts in aquifer material and evapotranspiration concentrates the water, and bicarbonate ions are removed by calcite precipitation. The result is sodium chloride water. Similar processes probably occur in the Smoke Creek Desert basin: ground water starts as a dilute concentration of sodium, calcium, and bicarbonate ions in water in the mountain blocks, loses the calcium beneath the alluvial fans, and becomes a sodium chloride water with high concentrations of dissolved solids near the playa.

The ground water analyzed from sites 33 and 2 (fig. 13) - along the ground-water flow path between the Honey Lake basin and Smoke Creek Desertcontains ions at similar concentrations. The comparable ion chemistry of the two sites is not conclusive evidence but does support the possibility of flow between the two basins. 
Site 14

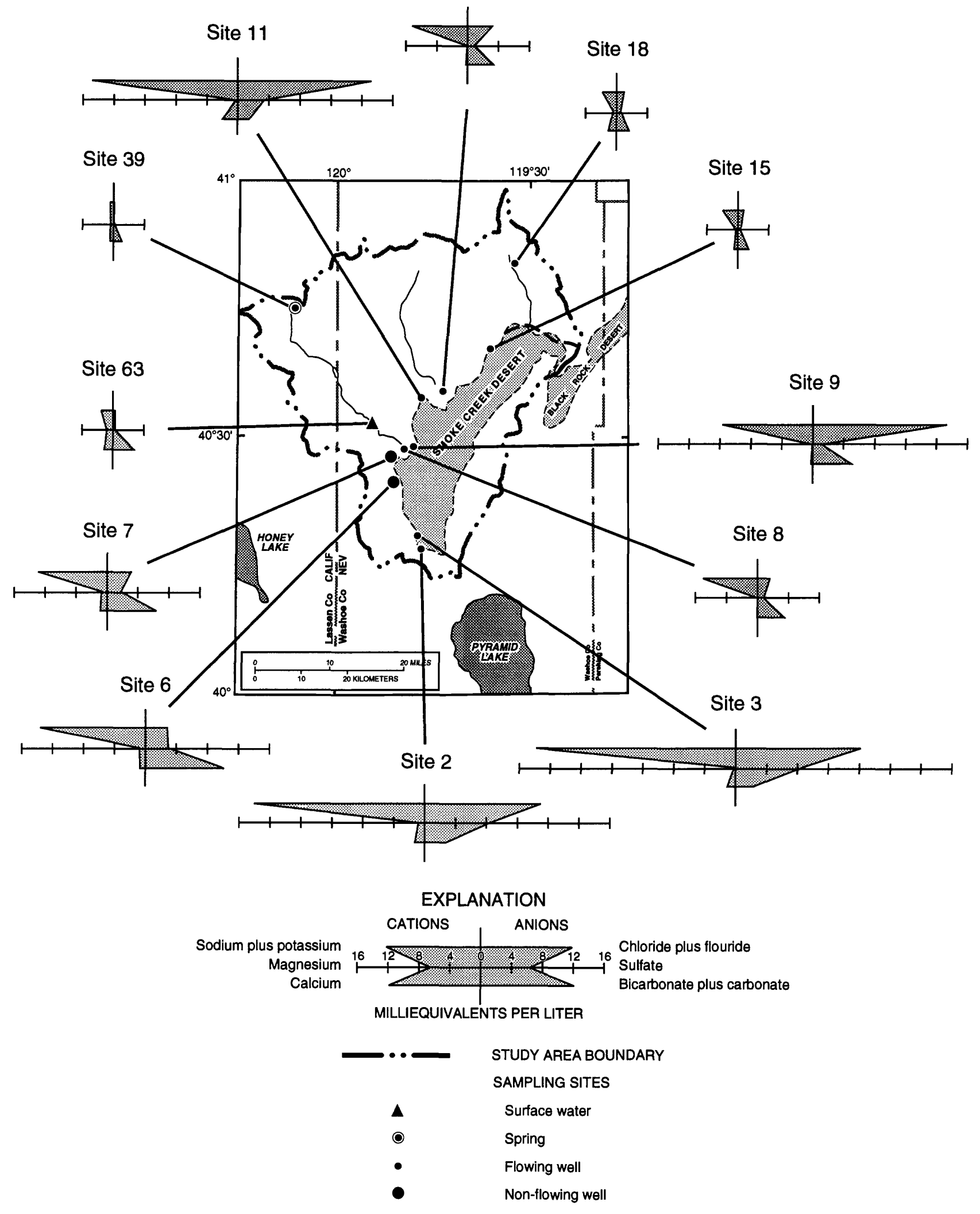

FIGURE 12.--Stiff diagrams showing concentrations of major ions at selected sites.

(Number is site in tables 4 and 5.) 


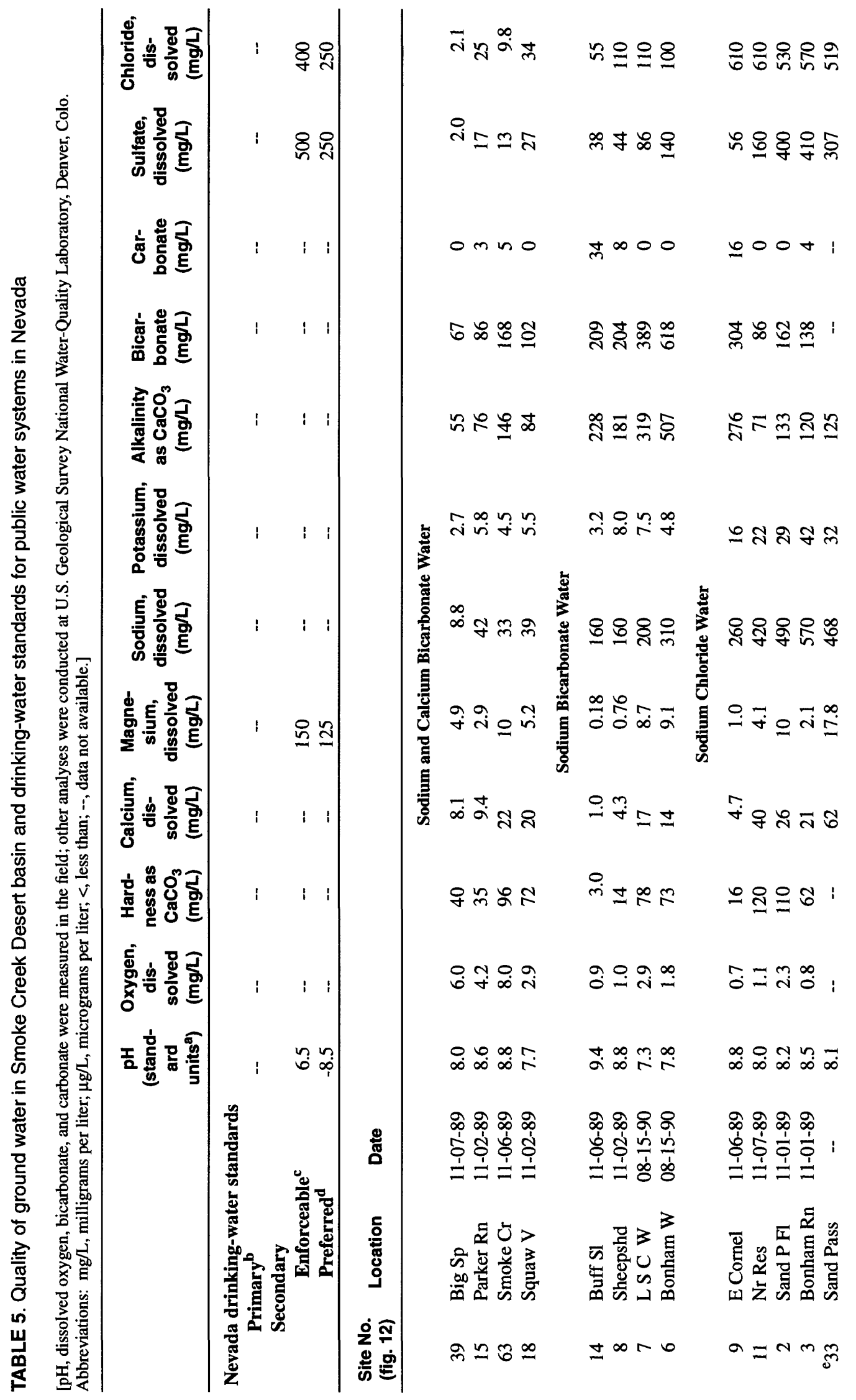




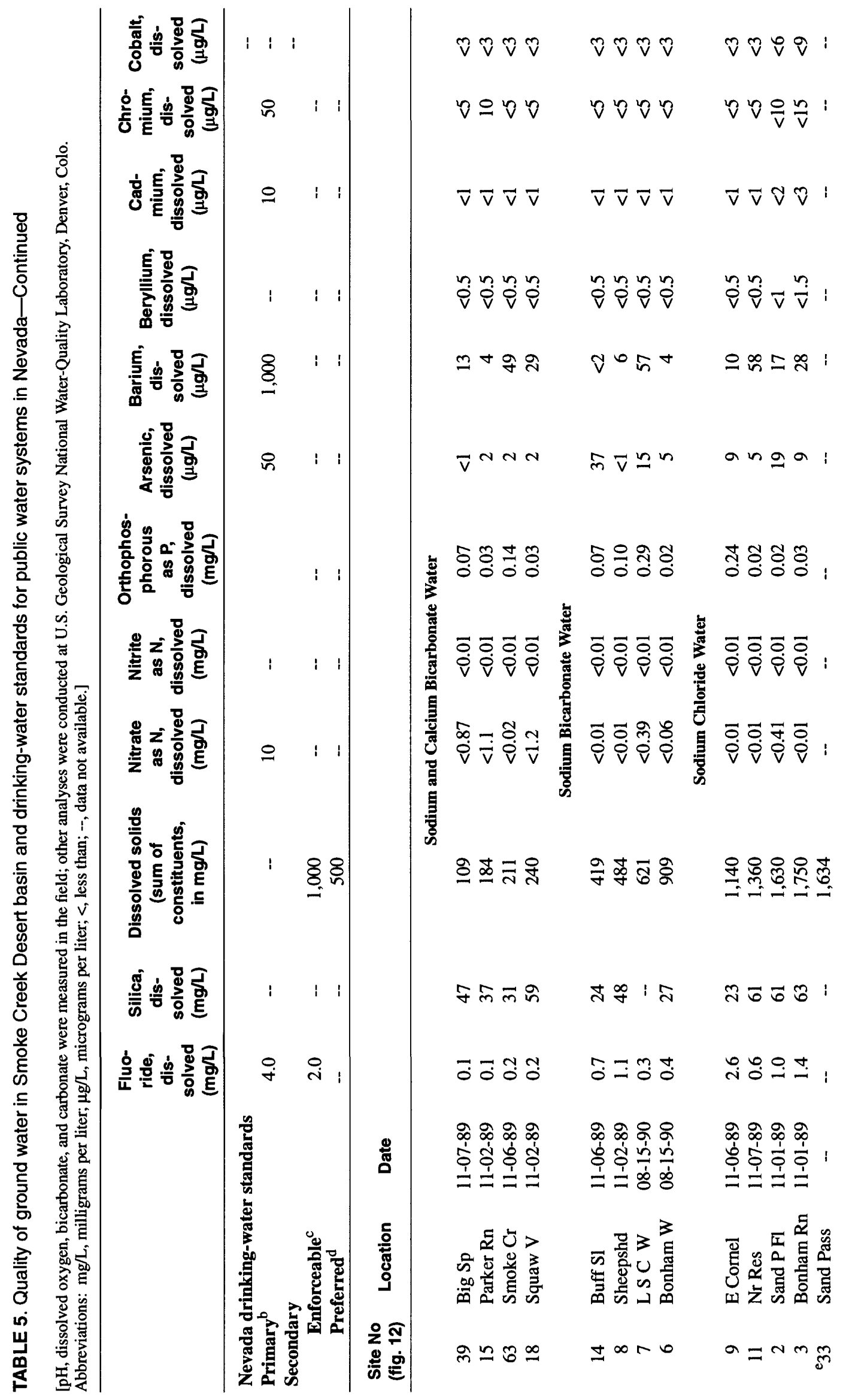




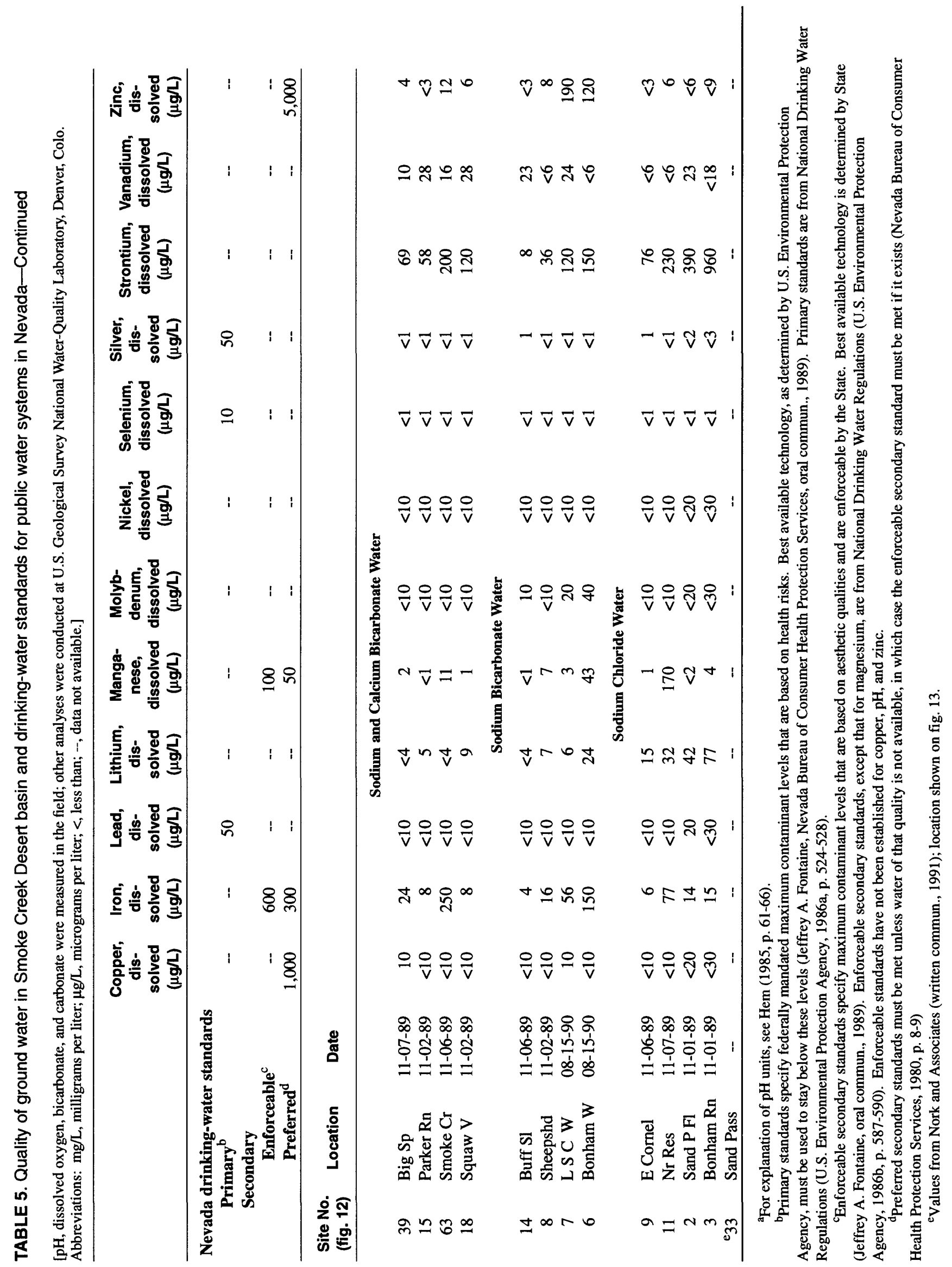




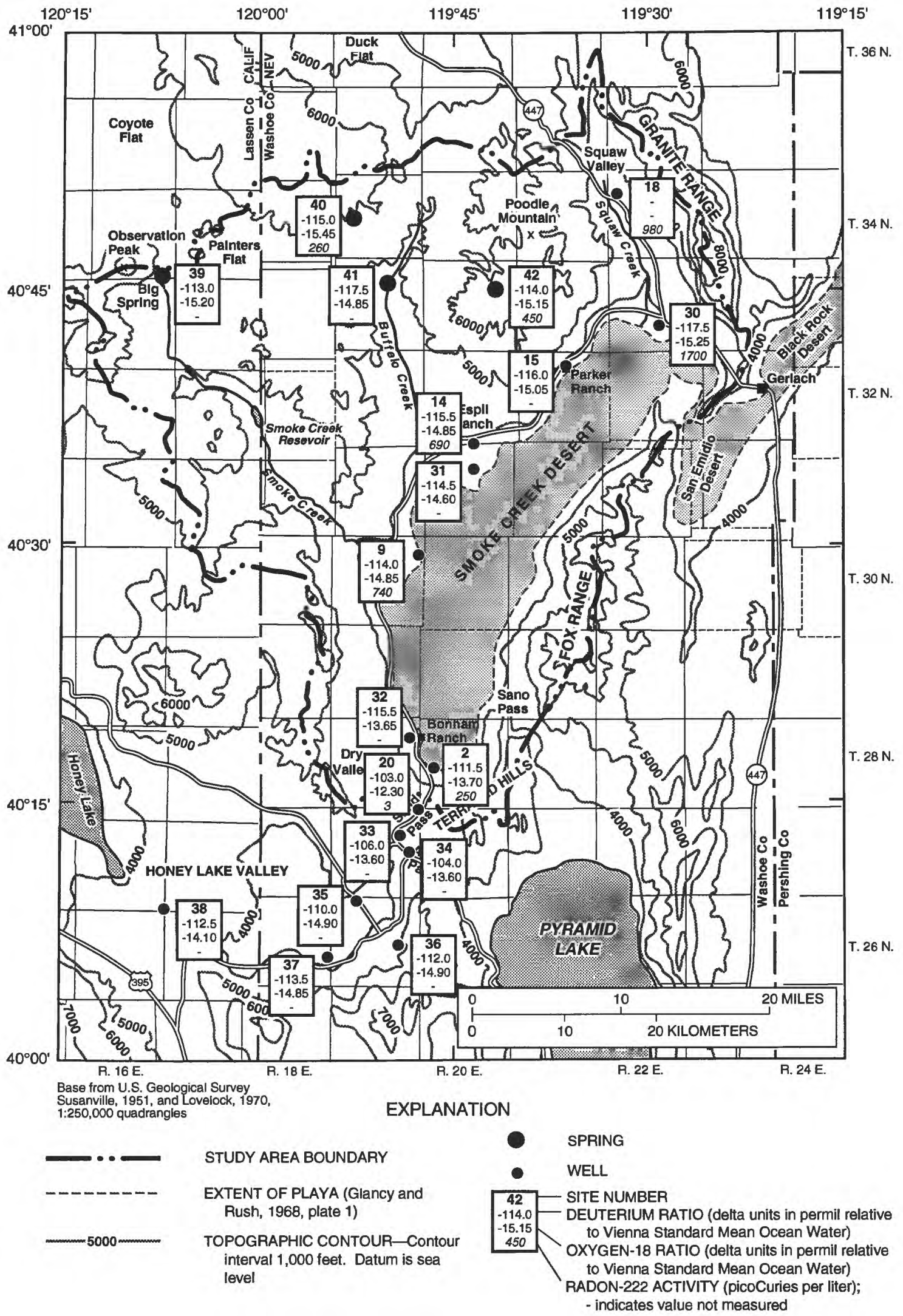

FIGURE 13.--Sampling sites, deuterium and oxygen-18 ratios, and radon-222 activities of ground water in Smoke Creek Desert basin. 


\section{Oxygen and Hydrogen Isotopes}

Ground-water samples from 11 sites (fig. 13) in the Smoke Creek Desert basin were analyzed for the stable isotopes of oxygen and hydrogen. Isotope concentration is measured as the ratio of oxygen-18 to oxygen-16 and the ratio of deuterium to hydrogen in the water molecule. These ratios are expressed in delta units $(\delta)$ as parts per thousand (permil) differences relative to the Vienna standard mean ocean water (V-SMOW; Fontes, 1980). The condensation history of precipitation determines its isotopic content. The most important factors are distance from the ocean, latitude, and altitude at which precipitation takes place (Fontes, 1980, p. 78). Because oxygen-18 and deuterium are part of the water molecule, their concentration remains constant as water moves through aquifer material unless the water dissolves large amounts of oxygencontaining minerals or evaporates. Oxygen-18 concentration plotted against deuterium concentration in precipitation shows a linear relation called the meteoric water line (Craig, 1961). Evaporation causes a shift upward and to the right of this line. Water that has been geothermally heated and reacts with oxygen-containing minerals becomes enriched in oxygen- 18 without affecting deuterium concentration; consequently, heating causes a horizontal shift to the right of the meteoric water line (fig. 14; Fontes, 1980, p. 78).

Isotope compositions from samples collected in the Honey Lake basin by Washoe County and in Honey Lake and Smoke Creek Desert basins by the U.S. Geological Survey are listed in table 6 and plotted in figure 14. Samples were analyzed at the U.S. Geological Survey Research Laboratory in Reston, Va., and at the Desert Research Institute laboratory in Las Vegas, Nev. Samples taken by Washoe County and the U.S. Geological Survey from the Ferrel well in Honey Lake Valley (site 37) and analyzed at both laboratories yielded comparable results.

The plots of isotope concentrations show that all samples lie to the right of the meteoric water line (fig. 14). This composition is typical of ground water in the Basin and Range Province because of some evaporation either before recharge or from soil in the discharge area. Samples from the Honey Lake basin and Smoke Creek Desert appear to be similar in their isotope composition with a few exceptions. Water from wells sampled near Sand Pass and Astor Pass (sites 20, 33 , and 34) is slightly heavier (less negative) than ground water sampled in the main parts of Honey Lake and Smoke Creek basins. Local, low-altitude recharge to the passes might result in the heavier isotope composition. Sites 33 and 34 are the only two wells tapping volcanic rocks; sites 39 through 42, however, are springs issuing from volcanic rocks. Thus, rock type does not seem to be the cause of the difference in isotope composition. Site 20 is a well located at the edge of a small isolated playa; its water was probably derived from water with an isotope composition similar to sites 33 and 34, but has been affected by evaporation. Site 2 , located near the south end of Smoke Creek Desert, and site 38, near the center of Honey Lake basin, could also have been slightly affected by evaporation. Site 32 is a well with a water temperature of $36^{\circ} \mathrm{C}$, and its location to the right of the other Smoke Creek Desert samples on figure 14 may be the result of oxygen exchange with minerals, resulting from geothermal heating.

Although water-level altitudes indicate a potential for ground-water flow from the Honey Lake basin towards Smoke Creek Desert, ground water at the depths sampled near Sand Pass (400-600 ft below land surface) with heavier isotope composition probably did not originate in the Honey Lake basin. Thus, if ground water moves from Honey Lake basin to Smoke Creek Desert basin, either it moves at depths greater than 400 to $600 \mathrm{ft}$, or it moves eastward across the divide north of Sand Pass into Smoke Creek Desert. The area to the north is underlain by volcanic rocks that are more permeable than the fine-grained sediments on the floor of the Honey Lake basin, so underflow through these rocks is considered possible.

Radon-222 activities in the ground-water samples collected are also shown on figure 13. The proposed maximum contaminant level for radon-222 in drinking-water is $300 \mathrm{pCi} / \mathrm{L}$ (U.S. Environmental Protection Agency, 1991, p. 33051). Radon-222 forms by radioactive decay of uranium, which is abundant in granitic rocks. Water samples from sites 18, 30, 42, 14, and 9 exceeded the proposed regulation for radon- 222 . Samples from sites 18 and 30 were the highest, probably because of their proximity to granodiorite in the Granite Range. 
TABLE 6. Deuterium and oxygen-18 composition and radon-222 activities of ground water sampled in Smoke Creek Desert and Honey Lake basins

\begin{tabular}{|c|c|c|c|c|c|c|}
\hline $\begin{array}{c}\text { Site } \\
\text { number } \\
\text { (fig. 13) }\end{array}$ & Location & $\operatorname{Lab}^{a}$ & $\begin{array}{c}\text { Well } \\
\text { depth } \\
\text { (ft) }\end{array}$ & $\begin{array}{c}\text { delta } \\
\text { Deuterium } \\
\text { (permii) }\end{array}$ & $\begin{array}{c}\text { deita } \\
\text { Oxygen-18c } \\
\text { (permil) }\end{array}$ & $\begin{array}{c}\text { Radon-222 } \\
\text { activityd }^{d} \\
\text { (pCi/L) }\end{array}$ \\
\hline 39 & Big Sp & USGS & -- & -113.0 & -15.20 & -- \\
\hline 40 & Norton $\mathrm{Sp}$ & USGS & -- & -115.0 & -15.45 & 260 \\
\hline 41 & Buffalo Sp & USGS & -- & -117.5 & -14.85 & -- \\
\hline 42 & Stockade Sp & USGS & -- & -114.0 & -15.15 & 450 \\
\hline 30 & Casey Rnch & USGS & -- & -117.5 & -15.25 & 1700 \\
\hline 15 & Parker Rnch & USGS & 208 & -116.0 & -15.05 & -- \\
\hline 14 & Nr Buffalo Sl & USGS & 98 & -115.5 & -14.85 & 690 \\
\hline 31 & Nr Hog Sl & USGS & 88 & -114.5 & -14.60 & -- \\
\hline 9 & E Cornell & USGS & 72 & -114.0 & -14.85 & 740 \\
\hline 32 & Bonham Rnch & USGS & 155 & -115.5 & -13.65 & -- \\
\hline 2 & Sand Pass Fl & USGS & -- & -111.5 & -13.70 & 250 \\
\hline 18 & Squaw Valley & USGS & -- & -- & -- & 980 \\
\hline 20 & Bonham Playa & DRI & 240 & -103.0 & -12.30 & -- \\
\hline 33 & Sand Pass & DRI & 580 & -106.0 & -13.60 & - \\
\hline 34 & Astor Pass & DRI & 440 & -104.0 & -13.6 & -- \\
\hline 35 & H L Playa & DRI & 260 & -110.0 & -14.90 & -- \\
\hline 36 & Cottonwood & DRI & 665 & -112.0 & -14.90 & -- \\
\hline 37 & Ferrel & DRI & 246 & -113.0 & -14.90 & -- \\
\hline 37 & Ferrel & USGS & 246 & -113.5 & -14.85 & -- \\
\hline 38 & SA D 2 & USGS & 700 & -112.5 & -14.10 & -- \\
\hline
\end{tabular}

${ }^{\text {a} U S G S, ~ s a m p l e ~ a n a l y z e d ~ a t ~ t h e ~ U . S . ~ G e o l o g i c a l ~ S u r v e y ~ l a b o r a t o r y, ~ R e s t o n, ~ V a . ; ~ D R I, ~ s a m p l e ~ a n a l y z e d ~}$ at Desert Research Institute laboratory, Las Vegas, Nev. (DRI data from written commun., Michael C. Widmer, Washoe County, 1990.)

b--, well depth not applicable or not known.

${ }^{\mathrm{c} D e u t e r i u m}$ and oxygen-18 values relative to Vienna Standard Mean Ocean Water; --, value not known.

${ }^{\mathrm{d}}$ Activities in picocuries per liter (pCi/L); --, activity not known.

\section{SUGGESTIONS FOR FUTURE STUDY}

The lack of subsurface data in and near the boundaries of Smoke Creek Desert leaves many questions about the hydrogeology of the basin unanswered. Installing observation wells in the volcanic rocks would allow observation of water levels, sampling for water quality, and estimation of hydrologic properties of the unit. Water-level measurements in the volcanic rocks, combined with geophysical data, could reveal the thickness of volcanic rocks and interbedded semiconsolidated deposits and allow evaluation of ground-water flow near the basin boundaries. Geophysical data would show the thickness of basin-fill deposits and provide a starting point for installing deep observation wells (greater than $200 \mathrm{ft}$ below land surface) in unconsolidated basin-fill deposits around the perimeter of the playa and on the playa. These wells would provide data on (1) the distribution of lithology within the deposits; (2) the thickness of the deposits and determination of the lateral extent of volcanic rocks beneath the valley floor; and (3) water levels, pressure head, and water-quality changes with depth.

Without data collected over a number of years, estimates of water-budget components are tenuous. Continued collection of surface-water data would aid in refining the water budget for the basin. Surface-water data needed include a continued record of streamflow in Smoke Creek; streamflow gain and loss along Smoke, Buffalo, and Squaw Creeks over a range of flow rates; 
and estimates of peak flow at currently ungaged streams. Estimates of peak flow could be obtained by operating crest-stage gages and applying indirect methods that allow estimation of the volume and frequency of flow at ungaged ephemeral streams (Moore, 1968). Continued collection of precipitation data is needed to refine the estimate of the distribution of average annual precipitation.
Measurement of evapotranspiration by phreatophytic vegetation and evaporation from bare soil is needed to refine the discharge component of the water budget. Also, the estimate of recharge by infiltration of precipitation could be refined by using models that include data on soils, vegetation, daily precipitation, and runoff (Bauer and Vaccaro, 1990; Leavesley and others, 1983).

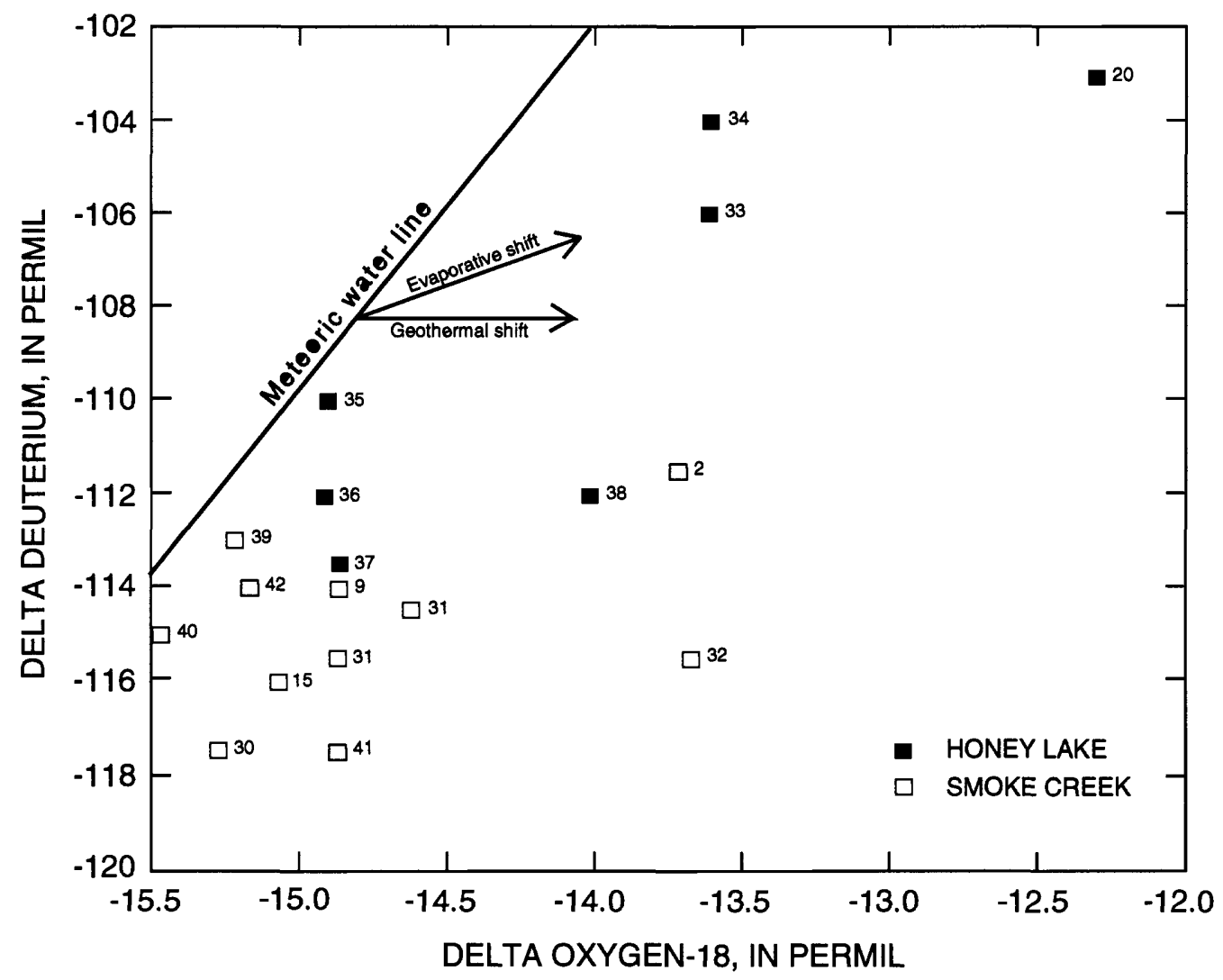

FIGURE 14.--Deuterium and oxygen-18 composition of ground water of Smoke Creek Desert basin and ground water in Honey Lake basin. Meteoric water line from Craig (1961). (Number indicates site in table 6.) 


\section{SUMMARY}

The Smoke Creek Desert basin, which covers about $1,200 \mathrm{mi}^{2}$ of relatively undeveloped land north of Reno, Nev., is a potential water source for the urban area of Washoe County. Hydrogeologic data were collected and compiled to begin a detailed data base to refine the hydrologic budget of the basin.

Metamorphic and granitic rocks that form the Granite and Fox Ranges are poorly water bearing and probably form a barrier to most ground-water flow along the eastern side of the basin. However, they probably lie thousands of feet deep beneath the northwestern part of the basin. Above the consolidated rocks are thick sections of volcanic rocks that form a broad, dissected plateau on the northern and western sides of the basin. These rocks are probably moderately to highly water bearing and represent a previously unrecognized aquifer. Outcrop patterns of the volcanic rocks indicate that they could underlie much of the western side of the valley floor. Semiconsolidated deposits that are poorly water bearing are interbedded with the volcanic rocks and also could make up a large part of the basin-fill deposits beneath the valley floor. Unconsolidated stream and alluvial-fan sediments surround the valley floor and are the main recognized aquifer in the basin. The thickness and lateral extent of the semiconsolidated and unconsolidated deposits remain largely unknown. However, along a profile across the center of the basin, geophysical data show a pediment buried about $500 \mathrm{ft}$ below land surface on the western margin of the valley floor; they also show that semiconsolidated and unconsolidated sediments are about $2,000 \mathrm{ft}$ thick near the center of the basin. The Smoke Creek Desert basin lies in a complex structural setting where the shape and extent of aquifers are controlled by movement along numerous faults. Details of the geometry of the aquifers in the basin lie buried under thousands of feet of volcanic rock and basin-fill material and remain largely unknown.

Precipitation in the study area ranges from more than $20 \mathrm{in} / \mathrm{yr}$ near the top of the Granite Range to less than $6 \mathrm{in} / \mathrm{yr}$ on the valley floor. About 8 in. of precipitation was measured at high altitudes on the west side of Smoke Creek Desert basin during water year 1990. This amount is comparable with that measured at Gerlach, which is near the valley floor.

A record of streamflow for Smoke Creek for most of water year 1989 and all of 1990 shows a large fluctuation in flow from a peak flow of about $860 \mathrm{ft}^{3} / \mathrm{s}$ to zero flow during summer months. The peak flow was caused by a melting snowpack in February 1989 . Total streamflow measured at the Smoke Creek gaging station was about 4,400 acre-ft for part of water year 1989 and about 1,300 acre-ft for water year 1990 . Streamflow measurements made along Smoke Creek in July and November of 1989 showed (1) an upper reach that gained about $2 \mathrm{ft}^{3} / \mathrm{s}$ with little loss to evapotranspiration; (2) an upper canyon reach that lost about $1.2 \mathrm{ft}^{3} / \mathrm{s}$ to infiltration and about 1.4 $\mathrm{ft}^{3} / \mathrm{s}$ to evapotranspiration; (3) a meadow reach that lost about $1.7 \mathrm{ft}^{3} / \mathrm{s}$ to infiltration and about $0.7 \mathrm{ft}^{3} / \mathrm{s}$ to evapotranspiration; (4) a lower canyon reach that showed little stream loss; and (5) a lower reach where 1.2 to $3.1 \mathrm{ft}^{3} / \mathrm{s}$ was lost to infiltration.

Miscellaneous measurements made on Squaw Creek showed that from 0.6 to $1.2 \mathrm{ft}^{3} / \mathrm{s}$ is gained near volcanic rocks in the upper reach of the stream, and all flow is lost to infiltration in the lower reach. On Buffalo Creek, miscellaneous measurements in volcanic rock outcrops showed a small loss during summer months and a gain of $0.7 \mathrm{ft}^{3} / \mathrm{s}$ during winter months.

During the February 1989 snowmelt, data from crest-stage gages show similar runoff peaks at Smoke and Buffalo Creeks, which have similar drainage areas, and a larger peak at Squaw Creek, which has a smaller drainage area. Squaw Creek, however, is higher in altitude and drains an area of lower permeability.

Water-level measurements in the basin show a ground-water gradient from the surrounding mountain blocks toward the playa and an upward gradient near the edge of the playa. Periodic measurements of water levels, pressure head, flow rate, temperature, and specific conductance show little change except for an area near ground-water withdrawals where water levels declined about $20 \mathrm{ft}$ from 1989 to 1990 .

Permeable volcanic rocks along the western, northern, and southern surface-water divides of the basin provide a potential avenue for interbasin ground-water flow. Although water-level data are sparse along the basin divide, previous workers have estimated annual flows of 200 acre- $\mathrm{ft}$ from San Emidio Desert into Smoke Creek Desert basin, 5,300 acre-ft from Honey Lake into Smoke Creek Desert basin, and 500 acre-ft from Painters Flat out of the basin toward the west. These estimates show that annual recharge to the Smoke Creek Desert basin could be about 19,000 acre-ft/yr. Water levels also indicate a potential for flow from Duck Flat to the Smoke Creek basin and from Smoke Creek basin to the Pyramid Lake basin. Additional water-level data are needed to 
determine if ground water flows across much of the western, northern, and southern topographic

boundaries of the basin.

Measurements of stream gain and loss provide data from which components of the basin water budget were estimated. About 2,800 acre-ft/yr was discharged from the upland volcanic rocks to streamflow. Streamflow provided a minimum of about 7,300 acre-ft/yr of recharge to unconsolidated sediments. About $1,500 \mathrm{acre}-\mathrm{ft} / \mathrm{yr}$ of streamflow is lost to evapotranspiration along the stream channel at Smoke Creek, and from 200 to $1,680 \mathrm{acre}-\mathrm{ft} / \mathrm{yr}$ of runoff was lost to evaporation of ponded water on the playa.

Measurements of specific conductance are 100 to $570 \mu \mathrm{S} / \mathrm{cm}$ in springs and streams in the mountains blocks, about $1500 \mu \mathrm{S} / \mathrm{cm}$ beneath alluvial fans, and as much as $5,000 \mu \mathrm{S} / \mathrm{cm}$ in flowing wells near the edge of the playa. Some areas near the playa have specific conductances of less than $1,000 \mu \mathrm{S} / \mathrm{cm}$ probably because of upgradient infiltration of dilute streamflow and subsurface recharge from volcanic rocks. Specific conductance of streamflow in Smoke Creek increased from $110 \mu \mathrm{S} / \mathrm{cm}$ at its source to $550 \mu \mathrm{S} / \mathrm{cm}$ before entering the playa. Standing water on the playa surface had a specific conductance of about $25,000 \mu \mathrm{S} / \mathrm{cm}$. A sample taken from shallow ground water near the edge of the playa measured about $70,000 \mu \mathrm{S} / \mathrm{cm}$. Ground water near the playa shows a general increase in specific conductance with well depth. Ground water of high specific conductance has a high density relative to fresh water and can produce downward flow beneath a playa; the density differential can drive circulation patterns toward the margin of the valley floor or out of the basin. However, the distribution of dissolved solids beneath the playa of Smoke Creek Desert is not known.

Of 13 samples analyzed for major-ion concentrations, all but two exceeded Nevada drinking-water standards. Ten samples exceeded drinking-water standards for $\mathrm{pH}$, dissolved solids, chloride, sulfate, and manganese. Most of the samples exceeding drinkingwater standards came from flowing wells near the playa. Major-ion concentrations show that ground water evolves from a dilute sodium and calcium bicarbonate water in the mountain blocks, to a sodium bicarbonate water beneath the alluvial fans, and finally to a sodium chloride water with a high concentration of dissolved solids near the edge of the playa.

Eleven samples collected from the Smoke Creek Desert basin were analyzed for stable isotopes of oxygen-18 and deuterium and were compared to samples collected in the Honey Lake basin. Isotope concentrations in both basins are similar except for samples taken near Sand Pass; therefore, if ground water does flow from Honey Lake basin to Smoke Creek basin, it must move at depths greater than about 400 to $600 \mathrm{ft}$ below land surface at Sand Pass or through volcanic rocks to the north.

\section{REFERENCES CITED}

Albers, J.P., 1967, Belt of sigmoidal bending and rightlateral faulting in the western Great Basin: Geological Society of America Bulletin, v. 78, no. 2, p. 143-156.

Bauer, H.H., and Vaccaro, J.J., 1990, Estimates of groundwater recharge to the Columbia Plateau regional aquifer system, Washington, Oregon, and Idaho, for predevelopment and current land-use conditions: U.S. Geological Survey Water-Resources Investigations Report 88-4108, $37 \mathrm{p}$.

Benson, L.V., and Paillet, F.L., 1989, The use of total lakesurface area as an indicator of climatic changeexamples from the Lahontan Basin: Quaternary Research, v. 32, p. 262-275.

Benson, L.V., and Thompson, R.S., 1987, Lake-level variation in the Lahontan Basin for the past 50,000 years: Quaternary Research, v. 28, p. 69-85.

Bonham, H.F., 1969, Geology and mineral deposits of Washoe and Storey Counties, Nevada: Nevada Bureau of Mines Bulletin 70, $40 \mathrm{p}$.

Bostic, R., Hitch, D., Van Gordon, L., and Swanson, R., 1991, Water resources data, Nevada, water year 1990: U.S. Geological Survey Water-Data Report NV-90-1, $358 \mathrm{p}$.

California Department of Water Resources, 1963, Northeastern counties ground water investigation: California Department of Water Resources Bulletin 98, v. 2, 32 plates.

Craig, Harmon, 1961, Isotopic variations in meteoric waters: Science, v. 133, no. 3465, p. 1702-1703.

Duffy, C.J., and Al-Hassan, Sumani, 1988, Groundwater circulation in a closed desert basin-topographic scaling and climatic forcing: Water Resources Research, v. 24, no. 10, p. 1675-1688.

Fontes, J. C., 1980, Environmental isotopes in groundwater hydrology, in Fritz, Peter, and Fontes, J. C., eds., Handbook of environmental isotope geochemistry: Amsterdam, Elsevier, v. 1A, p. 75-140.

Glancy, P.A., and Rush, F.E., 1968, Water-resources appraisal of Smoke Creek-San Emidio Desert area, Nevada and California: Nevada Department of Conservation and Natural Resources, Water ResourcesReconnaissance Report 44, 57 p. 
Handman, E.H., Londquist, C.J., and Maurer, D.K., 1990, Ground-water resources of Honey Lake Valley, Lassen County, California, and Washoe County, Nevada.: U.S. Geological Survey Water-Resources Investigations Report 90-4050, 112 p.

Hardman, George, 1965, Nevada precipitation map, adapted from map prepared by George Hardman, Victor Kral, and others, 1936: University of Nevada, Reno, Agricultural Experiment Station Bulletin 185, 27 p.

Hem, J.D., 1985, Study and interpretation of the chemical characteristics of natural water: U.S. Geological Survey Water-Supply Paper 2254, 283 p.

Jachens, R.C., and Moring, B.C., 1990, Maps of the thickness of Cenozoic deposits and the isostatic residual gravity over basement for Nevada: U.S. Geological Survey Open-File Report 90-404, 15 p.

Leavesley, G.H., Litchy, R.W., Troutman, M.M., and Saindon, L.G., 1983, Precipitation-runoff modeling system-user's manual: U.S. Geological Survey WaterResources Investigations Report 83-4238, 207 p.

Lindsley, D.H., Andreasen, G.E., and Balsley, J.R., 1966, Magnetic properties of rocks and minerals, in Clark, S.P., Jr., ed., Handbook of physical constants:

Geological Society of America Memoir 97, p. 543-552

Lydon, P.A., Gay, T.E., and Jennings, C.W., 1960, Geologic map of California, Westwood [Susanville] sheet: California Division of Mines and Geology, scale $1: 250,000$.

Macdonald, G.A., 1966, Geology of the Cascade Range and the Modoc Plateau, in Bailey, E.H., ed., Geology of Northern California, California Division of Mines and Geology Bulletin 190, p. 65-96

Moore, D.O., 1968, Estimating mean runoff in ungaged semiarid areas: U.S. Geological Survey, Water Resources Bulletin 36, 11 p.

Nevada Bureau of Consumer Health Protection Services, 1980, Water supply regulations-Part 1, water quality standards-Monitoring, record keeping, and reporting: Nevada Division of Health, $27 \mathrm{p}$.

Pupacko, Alex, Van Gordon, L.C., Swartwood, J.R., and Collins, R.P., 1990, Water resources data, Nevada, water year 1989: U.S. Geological Survey Water-Data Report NV-89-1, 342 p.

Robinson, T.W., 1970, Evapotranspiration by woody phreatophytes in the Humboldt River Valley near Winnemucca, Nevada: U.S. Geological Survey Professional Paper 491-D, $41 \mathrm{p}$.

Rush, F.E., 1968, Index of hydrographic areas in Nevada: Nevada Division of Water Resources, Information Report 6, $38 \mathrm{p}$.

Sales, J.K., 1966, Structural analysis of the Basin and Range Province in terms of wrench-faulting: Reno, University of Nevada, unpublished Ph.D. thesis, $178 \mathrm{p}$.

Sanford, W.E., 1989, Ground-water flow and solute transport at a playa lake on the Southern High Plains:
Transactions, American Geophysical Union, v. 70, no. 43, p. 1101 .

Shawe, D.R., 1965, Strike-slip control of Basin-Range structure indicated by historical faults in western Nevada: Geological Society of America Bulletin, v. 76, no. 12, p. 1361-1377.

Stewart, J.H., 1988, Tectonics of the Walker Lane Belt, western Great Basin-Mesozoic and Cenozoic deformation in a zone of shear, in Ernst, W.G., ed., Metamorphism and crustal evolution of the western United States, v. 7: Englewood Cliffs, N.J., Prentice-Hall Robey, p. 683-713.

Thomas, J.M., Welch, A.H., and Preissler, A.M., 1989, Geochemical evolution of ground water in Smith Creek Valley-a hydrologically closed basin in central Nevada, U.S.A.: Applied Geochemistry, v. 4, p 493-510.

U.S. Environmental Protection Agency, 1986a, Maximum contaminant levels (subpart B or part 141, National interim primary drinking-water regulations): U.S. Code of Federal Regulations, Title 40, Parts 100 to 149, revised as of July 1, 1986, p. 524-528.

-1986b, Secondary maximum contaminant levels (section 143.3 of part 143, National secondary drinking-water regulations): U.S. Code of Federal Regulations, Title 40 , parts 100 to 149 , revised as of July 1 , 1986, p. 587-590.

U.S. Environmental Protection Agency, 1991, Proposed rule for primary maximum contaminant levels for radionuclides: Federal Register, U.S. Code of Federal Regulations, July 18 , 1991 , v. 56 , no. 138 , p. 33050-33127.

Wagner, D.L. and Saucedo, G.J., 1993, Reconnaissance geologic map of Shinn Mountain, 15-Minute Quadrangle, Lassen County, California: California Division of Mines and Geology, Open File Report 91-24, scale $1: 62,500$.

Webring, Michael, 1985, SAKI: A Fortran program for generalized linear inversion of gravity and magnetic profiles: U.S. Geological Survey Open-File Report 85-122, 29 p.

Welch, A.H., and Preissler, A.M., 1990, Geothermal resources of the western arm of the Black Rock Desert, northwestern Nevada-Part II, Aqueous geochemistry and hydrology: U.S. Geological Survey WaterResources Investigations Report 87-4062, 91 p.

Wise, D.U., 1963, An outrageous hypothesis for the tectonic pattern of the North American Cordillera: Geological Society of America Bulletin, v. 74, p. 357-362.

Wood, W.W., Sanford, W.E., Kraemer, T.F., Konikow, L.F., Jones, B.F., and Webster, D.M., 1989, Hydrologic control of solute chemistry in lake/ground-water systems in arid and semi-arid areas of low topographic relief [abs:]: Transactions, American Geophysical Union, v. 70, no. 43, p. 1100. 